\title{
Technological Progresses in Monoclonal Antibody Production Systems
}

\author{
Maria Elisa Rodrigues, Ana Rita Costa, Mariana Henriques, Joana Azeredo, and Rosário Oliveira \\ IBB-Institute for Biotechnology and Bioengineering, Centre of Biological Engineering, University of Minho, Campus de Gualtar 4710- \\ 057 Braga, Portugal
}

DOI 10.1002/btpr.348

Published online December 30, 2009 in Wiley InterScience (www.interscience.wiley.com).

Monoclonal antibodies (mAbs) have become vitally important to modern medicine and are currently one of the major biopharmaceutical products in development. However, the high clinical dose requirements of mAbs demand a greater biomanufacturing capacity, leading to the development of new technologies for their large-scale production, with mammalian cell culture dominating the scenario. Although some companies have tried to meet these demands by creating bioreactors of increased capacity, the optimization of cell culture productivity in normal bioreactors appears as a better strategy. This review describes the main technological progresses made with this intent, presenting the advantages and limitations of each production system, as well as suggestions for improvements. New and upgraded bioreactors have emerged both for adherent and suspension cell culture, with disposable reactors attracting increased interest in the last years. Furthermore, the strategies and technologies used to control culture parameters are in constant evolution, aiming at the on-line multiparameter monitoring and considering now parameters not seen as relevant for process optimization in the past. All progresses being made have as primary goal the development of highly productive and economic mAb manufacturing processes that will allow the rapid introduction of the product in the biopharmaceutical market at more accessible prices. (C) 2009 American Institute of Chemical Engineers Biotechnol. Prog., 26: 332-351, 2010 Keywords: monoclonal antibodies, bioreactors, scale-up, cell culture, operation modes

\section{Introduction}

In the last decades, monoclonal antibodies (mAbs) have become increasingly important in terms of medical research, diagnosis, and therapy. They constitute more than $30 \%$ of total biopharmaceutical production ${ }^{1,2}$ and are the largest class of proteins currently under clinical trials. ${ }^{3}$ Several mAbs have been approved for use in therapeutic applications, as summarized in Table 1 (for a more extensive and detailed list that includes mAbs approved for diagnostic purposes as well as mAbs under development, consult the Immunogenetics (IMGT) webpage http://imgt.cines.fr/textes/IMGTrepertoire/ GenesClinical/monoclonalantibodies/\#Approval_antibodies).

The major percentage of the mAbs approved and under trials is produced by mammalian cells ${ }^{4}$ because of their ability to perform human-like post-translational modifications that result in full-active product. ${ }^{5}$

Generally, therapies with mAbs require the use of high doses over prolonged periods of time. ${ }^{6}$ Therefore, the production of these products needs to be done at large scale to meet the market demands. ${ }^{6}$ Moreover, it is desirable to have economic, highly productive, and consistent manufacturing processes, able to deliver health benefits to patients in a quick way. ${ }^{6}$ The achievement of an economic highly productive process currently constitutes a major biotechnological challenge. ${ }^{7}$ With this aim, several production systems have been developed, with frequent updates and improvements,

Correspondence concerning this article should be addressed to $\mathrm{M}$. Henriques at mcrh@deb.umiho.pt. resulting in a wide range of available technologies for largescale $\mathrm{mAb}$ production. In this article, it is intended to give a critical review of these systems, pointing their strengths, recent advances, as well as major limitations that still need to be surpassed.

\section{Production Systems}

In the laboratory, conventional low-density cell culture methods are used for production of mAbs at low concentrations $(1-100 \mu \mathrm{g} / \mathrm{mL}){ }^{3}$ This small-scale cell culture provides sufficient amounts for research and diagnostic purposes. However, the market needs for therapeutic products require large-scale manufacturing capacity, ${ }^{3}$ with demands on mAbs of $100-1,000 \mathrm{~kg} /$ year, which can only be achieved in large bioreactors and by efficient processes that produce several kg/day. ${ }^{8,9}$

\section{Systems for small-scale production}

Small-scale culture systems usually have a simple design and a low level of instrumentation and control. ${ }^{10}$ In these systems, cells are usually grown adherently, because this is the normal/physiological mode of growth of mammalian cells, and the process of adaptation to suspension can be time-consuming. Nevertheless, because adherent culture has the major drawback of limited surface area for growth, ${ }^{11}$ some small-scale systems for suspension culture have also been developed. 
Table 1. Monoclonal Antibodies Approved for Clinical Application Until 2009

\begin{tabular}{|c|c|c|c|}
\hline Product & Company & Clinical Indication & Approval \\
\hline ORTHOCLONE & Ortho Biotech & Acute kidney transplant rejection & 1986 \\
\hline $\mathrm{OKT}^{\circledR}$ & & Heart transplant rejection, liver transplantation & 1993 \\
\hline REOPRO $^{\circledR}$ & Centocor/Eli Lilly & Percutaneous transluminal coronary angioplasty & 1994 \\
\hline PANOREX $^{\circledR}$ & Centocor/GlaxoSmithKline & Colon cancers & 1995 \\
\hline ZENAPAX $^{\circledR}$ & F. Hoffmann-La Roche & Acute kidney transplant rejection & 1997 \\
\hline \multirow[t]{2}{*}{ MABTHERA $^{(} /$RITUXAN $^{\circledR}$} & $\begin{array}{l}\text { Biogen IDEC/Genzyme/F. } \\
\text { Hoffmann-La Roche }\end{array}$ & $\begin{array}{l}\text { Follicular CD20 positive non-Hodgkin's } \\
\text { B-cell lymphoma (NHL), } \\
\text { non-Hodgkin's B-cell lymphoma (NHL) }\end{array}$ & 1997 \\
\hline & & Rheumatoid arthritis (RA) & 2006 \\
\hline SIMULECT $^{\circledR}$ & Novartis & Renal transplant rejection & 1998 \\
\hline SYNAGIS $^{\circledR}$ & Abbott/MedImmune & Respiratory Syncytial virus disease & 1998 \\
\hline HERCEPTIN $^{\circledR}$ & F. Hoffmann-La Roche/Genentech & Metastatic breast cancers overexpressing ERBB2 & 1998 \\
\hline \multirow[t]{3}{*}{ REMICADE $^{(}$} & Centocor & Crohn's disease & 1998 \\
\hline & & $\begin{array}{l}\text { Ankylosing spondylitis, psoriatic } \\
\text { arthritis, ulcerative colitis }\end{array}$ & 1999 \\
\hline & & Rheumatoid arthritis (RA) & 2001 \\
\hline MYLOTARG $^{\circledR}$ & Wyeth & Acute myeloid leukemia & 2000 \\
\hline CAMPATH $^{\circledR} /$ MABCAMPATH $^{\circledR}$ & Berlex/Genzyme/Millennium & B cell chronic lymphocytic leukemia & 2001 \\
\hline HUMIRA $^{\circledR} /$ TRUDEXA $^{\circledR}$ & Abbott & Psoriatic and rheumatoid arthritis & 2002 \\
\hline ZEVALIN $^{\circledR}$ & Biogen IDEC/Schering AG & Non-Hodgkin's B-cell lymphoma & 2002 \\
\hline RAPTIVA $^{(}$ & $\begin{array}{l}\text { Genentech/Merck Serono } \\
\text { International/Xoma }\end{array}$ & Psoriasis & 2003 \\
\hline XOLAIR ${ }^{\circledR}$ & Genentech/Novartis/Tanox & Allergic asthma, severe persistent asthma & 2003 \\
\hline $\mathrm{BEXXAR}^{\circledR}$ & GlaxoSmithKline/Corixa & $\begin{array}{l}\text { Follicular CD20 positive non-Hodgkin's } \\
\text { B-cell lymphoma (NHL) }\end{array}$ & 2003 \\
\hline $\operatorname{AVASTIN}^{\circledR}$ & Genentech & $\begin{array}{l}\text { Metastatic colorectal cancers, metastatic } \\
\text { non-small-cell lung cancers }\end{array}$ & 2004 \\
\hline ERBITUX $^{\circledR}$ & Merck \& Co/ImClone & Metastatic colorectal cancers & 2004 \\
\hline TYSABRI $^{\circledR}$ & Biogen IDEC/Elan & Multiple sclerosis & 2004 \\
\hline THERACIM $^{\circledR}$ & YM BioSciences & Glioma cancers & 2004 \\
\hline VECTIBIX $^{\mathrm{TM}}$ & Amgen & Colorectal cancers & 2006 \\
\hline LUCENTIS $^{\circledR}$ & Genentech/Novartis & Neovascular age-related macular degeneration & 2006 \\
\hline SOLIRIS $^{\mathrm{TM}}$ & Alexion & Paroxysmal nocturnal hemoglobinuria (PNH) & 2007 \\
\hline CIMZIA $^{(\circledR)}$ & Celltech, UCB & Crohn's disease & 2008 \\
\hline
\end{tabular}

Adherent Culture. For adherent culture, the typical systems used in laboratory scale are T-flasks, petri dishes, and multiwell plates. These systems are maintained in a humidified carbon dioxide $\left(\mathrm{CO}_{2}\right)$ incubator to provide a controlled environment for cell growth.

In anchorage-dependent cultures, the cell concentration possible to achieve is directly proportional to the surface area available for growth. ${ }^{10}$ Therefore, the scale increase for these cultures involves the amplification of the growth surface. One way to provide larger surface areas is to use multilayered stacked plate systems, such as Cell Factory (NalgeNunc) and CellCube (Costar) (Figures 1a,b). ${ }^{12-14}$ In these systems, because of the increased surface-to-volume ratio, high cell concentrations can be achieved, which in the case of CellCube is added by the continuous medium circulation that supplies oxygen and nutrients to the cells. ${ }^{14}$ However, heterogeneity of fluid flow has been observed in this system, resulting in nonuniform cell growth patterns and shear stress. ${ }^{14}$ Furthermore, both Cell Factory and CellCube operation are usually tedious, time-consuming, and with inefficient utilization of space. ${ }^{13}$

Another system commonly used to increase surface area, and therefore obtain higher cell and product concentrations, is roller bottles (Figure 1c). ${ }^{15,16}$ In this technology, cells are seeded into the roller bottles that are filled to $10-30 \%$ of their capacity with medium and slowly rotated, allowing cells to adhere and assuring their regular wetting. ${ }^{4}$ Apart from the increased surface area for growth and low shear rates, ${ }^{17,18}$ roller bottles have other advantages, such as very high oxygen transfer rates (supplied by the ample bottle "headspace" ) and the ease of scale-up that is simply done by increasing the number of units handled in parallel. ${ }^{4,19}$
However, the handling of a large number of roller bottles simultaneously can be tedious, ${ }^{13}$ labor-intensive, ${ }^{20}$ prone to contamination, and difficult to control product quality. ${ }^{20}$ This has led to the development of automated systems to handle roller bottle cultures (e.g., the RollerCell system marketed by Cellon, $\left.\mathrm{SA}^{21}\right){ }^{22}$

Furthermore, roller bottles only operate as batch or fedbatch systems, which prevents them from achieving cell densities and antibody secretion rates as high as the ones attained in continuous perfusion systems. ${ }^{4,19,23}$ A possible way to overcome this limitation is to use roller bottles operating on apparatuses that provide a continuous supply of nutrients and oxygen to the cells. ${ }^{19,23}$ This can be done by using a pump that delivers the culture medium from a fresh medium reservoir into the growth chamber of the bottle (spiroll bottle ${ }^{19}$ ) or by using a medium recirculation loop (CPRB-continuous perfusion roller bottle ${ }^{23}$ ) (Figures 1d,e). Higher cell densities can then be achieved in these models, as well as maintenance of cultures over longer periods of time, resulting in increased volumetric productivities.

All the systems mentioned, although achieving higher cell concentrations and productivities than the traditional laboratory methods of culture (T-flask, petri dishes, and multiwell plates), are not commonly used for large-scale industrial production. This is due to their limitations in terms of high costs (labor, equipment, and consumables), considerable risk of contamination, and poor control of culture parameters. ${ }^{10}$

Suspension Culture. When compared with adherent culture, in suspension systems cell concentration is independent of the surface area available, which allows increased cell densities and consequently higher product concentrations. The systems used for adherent culture (i.e., T-flasks, petri 

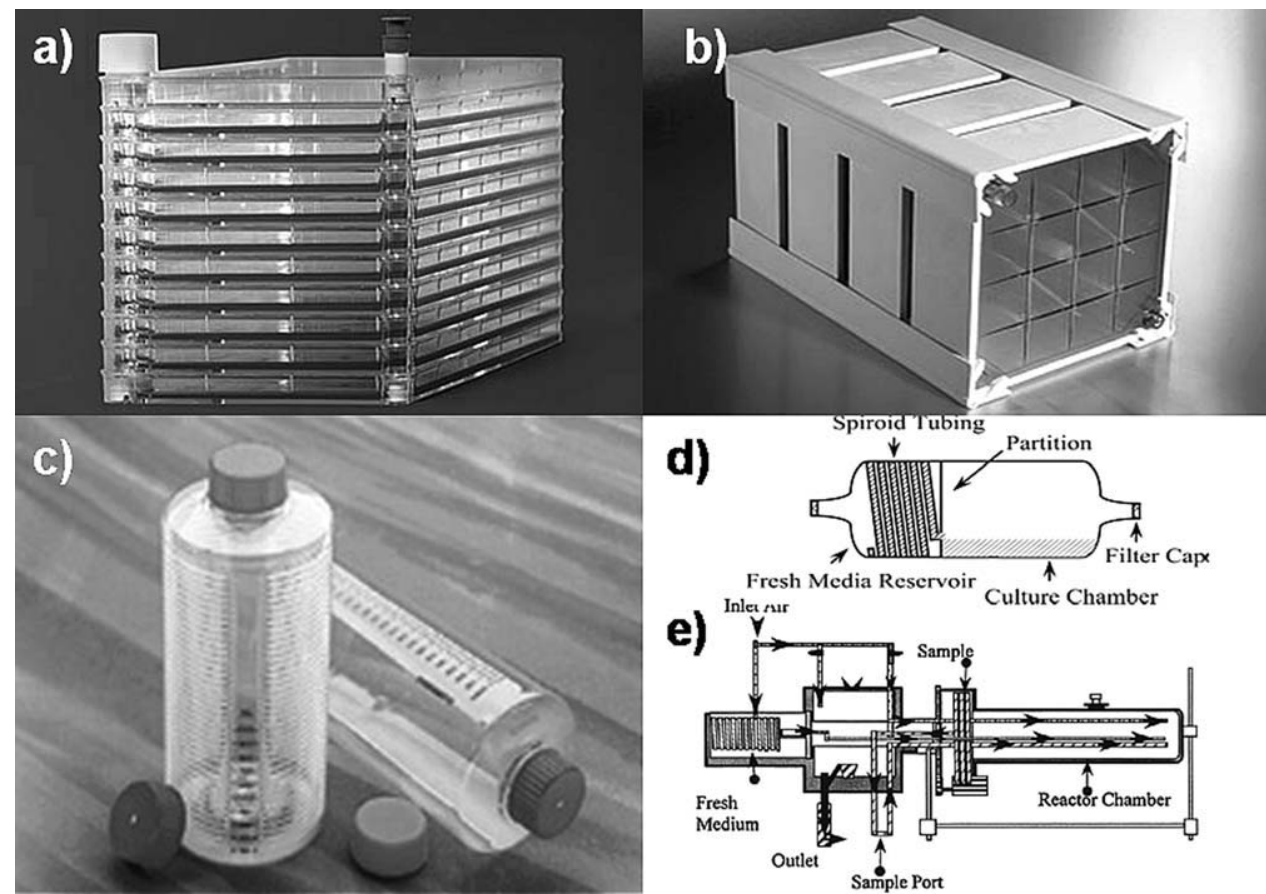

e)

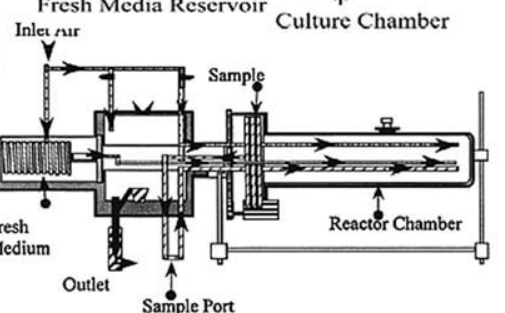

Figure 1. Systems for adherent culture in small scale.

(a) Cell Factory (www.fisher.co.uk), (b) Cell Cube (http://catalog2.corning.com), (c) Roller Bottle (www.sigmaaldrich.com), (d) Spi-roll Bottle, ${ }^{19}$ and (e) CPRB. ${ }^{23}$

dishes, and microtiter plates) can also be used for suspension cell propagation. ${ }^{10}$ Particularly, shaken microtiter plates are highly used for purposes of screening and optimization in cell culture, ${ }^{24}$ although the problem of evaporation limits its use for extended cultures. ${ }^{4}$

For the same purpose of screening, in media development trials, centrifuge tubes with ventilated caps can also be used for culturing cells in suspension. ${ }^{10,25}$

However, despite the fact that adherent systems can be used for suspended cultures, more adequate methods are available (Figure 2). These include shake flasks, ${ }^{26,27}$ roller bottles, ${ }^{19}$ and spinner flasks, ${ }^{10}$ that have been used for cultivation of many different suspension cell lines for a variety of applications within preclinical research, process development, and for expansion of inoculum in production. ${ }^{4,10}$

The advantages of these suspension-specific systems comparing to the stationary methods include the non-cell-adherent materials used in their construction, as well as a proper design that are ideal for maintaining a suspension culture without problems of cell deposition or adherence. Although oxygen transfer is improved because of the larger gas/liquid surface and agitation, oxygen limitations are still a major drawback that does not allow high cell densities to be achieved. ${ }^{4,10,28}$ Attempts to minimize this problem include sparging with Oxygen $\left(\mathrm{O}_{2}\right)$ /air, the superspinner ${ }^{29}$ (Figure 2c) that uses microporous membranes through which an air/ $\mathrm{CO}_{2}$ mixture is pumped, and the CELLine 1000 device, ${ }^{30}$ (Figure 2d) which has separate growth and medium chambers that allow more frequent and easier medium changes, with direct oxygenation and easy product isolation.

This system improves oxygen transfer rates, supporting high cell density $\left(10^{7}-10^{8}\right.$ cells $\left./ \mathrm{mL}\right)$ and generating a high $\mathrm{mAb}$ concentration $(0.7-2.5 \mathrm{mg} / \mathrm{mL})$ within a period of 2 months, but is still limited to a 1-2 L volume of culture per batch. $^{30}$

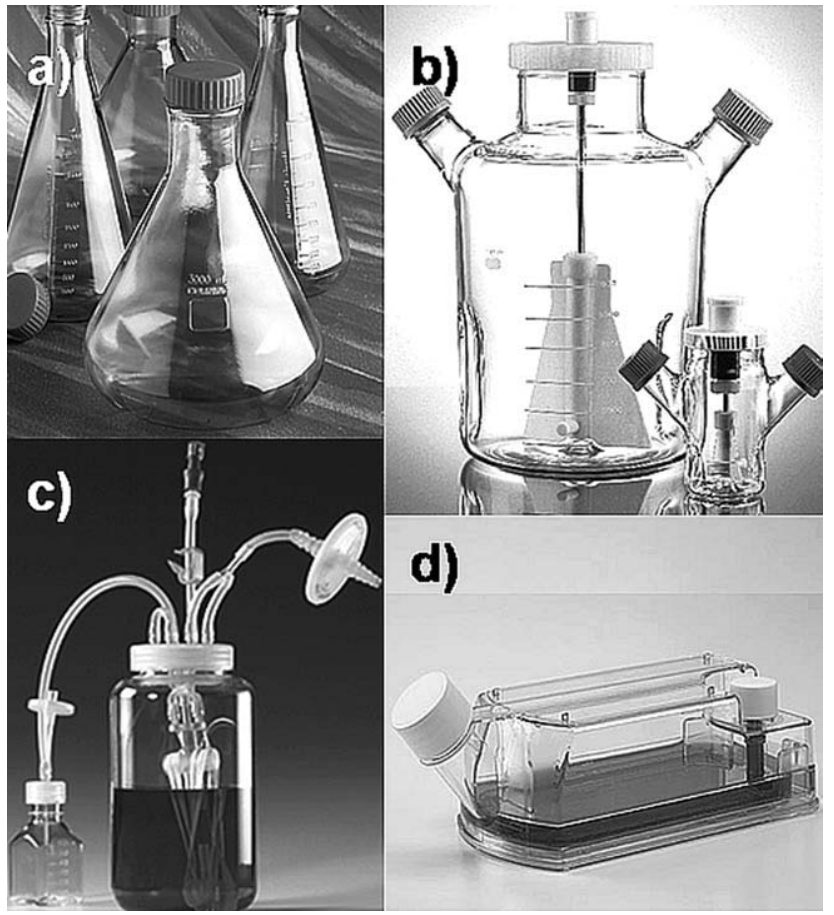

Figure 2. Systems for suspension culture in small scale.

(a) Shake flasks (www.sigmaaldrich.com), (b) Spinner flasks (www.sigmaaldrich.com), (c) Superspinner (www. pharmaceuticalonline.com), and (d) CeLLine 1000 (www. sartorius-stedim.com).

The limitations of oxygen transfer and poor control of the culture parameters inherent to the aforementioned devices only allow for small- or medium-scale production. To achieve large-scale production, other systems had to be developed. 


\section{Systems for large-scale production}

The high demands for mAbs gave rise to the development of different bioreactors and culture systems for large-scale production in mammalian cell culture. These systems are constantly evolving to overcome some key barriers of largescale processing, such as oxygen supply limitations, waste product accumulation, the need for more sophisticated process control, shear sensitivity of animal cells, and the challenges of growing adherent cell lines at large scale. ${ }^{31}$ Although some of these limitations have been surpassed, new ones have arisen. These include the maximization of the productivity while maintaining product quality, removal of all animal-derived components from cell culture medium, minimization of contamination during large-scale production, and control of $\mathrm{CO}_{2}$ removal. $^{9}$

For large-scale production, suspension cell-culture processes are usually the system of choice. Nevertheless, adherent culture systems are also being developed, because they can be indispensable to certain applications.

Suspension Culture. Suspension cell systems are the usual choice for large-scale production because of the wellunderstood principles of scale-up, the ease of process control, ${ }^{9}$ and the higher surface-to-volume ratio when compared with the adherent cell systems, ${ }^{10}$ which result in more efficient processes.

For culturing cells in suspension, agitation and aeration are critical and can cause shear damage to the cells. These negative effects can be minimized by using shear-protecting agents, such as Pluronic F68 (proposed mechanism of action reviewed by Gigout et al. ${ }^{32}$ ) or by appropriate reactor design and control. ${ }^{9}$ It should be taken into account that although many cell types can be adapted to suspension, this is still limiting the choice of cell line and is time-consuming, increasing the timeline for process development.

The most commonly used suspension culture systems for production of $\mathrm{mAb}$ are the stainless steel stirred tank, ${ }^{33}$ the airlift, ${ }^{34}$ and disposable ${ }^{28}$ bioreactors. Some specific advantages and limitations of these reactors, as well as recent developments, will be addressed later.

Stainless steel stirred tank bioreactor. The traditional and most widely used bioreactor type for mAb production is the stainless steel stirred tank bioreactor (STR) (Figure 3). ${ }^{9,10,35}$ This is mainly due to the broad knowledge and experience acquired from microbial fermentation. ${ }^{10}$ This results in better characterized and familiar scale-up principles and mechanical designs for sterilization and cleaning, when compared with other bioreactor types. ${ }^{10}$ This knowhow also facilitates the regulation/approval of the process of production, because the regulatory agencies are experienced with products obtained from STR in different modes of operation. $^{10}$

Other advantages of STR include the high mass/gas-transfer coefficient values, ${ }^{35}$ the high flexibility ${ }^{35}$ in terms of applicable working volumes (up to $15,000 \mathrm{~L}^{37}$ ), and the suitability for different cell types, operation modes, and products, which results in reduction of costs. ${ }^{10}$

Furthermore, good culture conditions such as temperature control, culture $\mathrm{pH}$, dissolved oxygen (DO) level, low agitation rate, and aeration with mixed gas and well-controlled conditions are supported and fulfilled by this bioreactor. ${ }^{35}$ This accurate control of culture conditions allows robust $\mathrm{mAb}$ production in STR with most commercially available

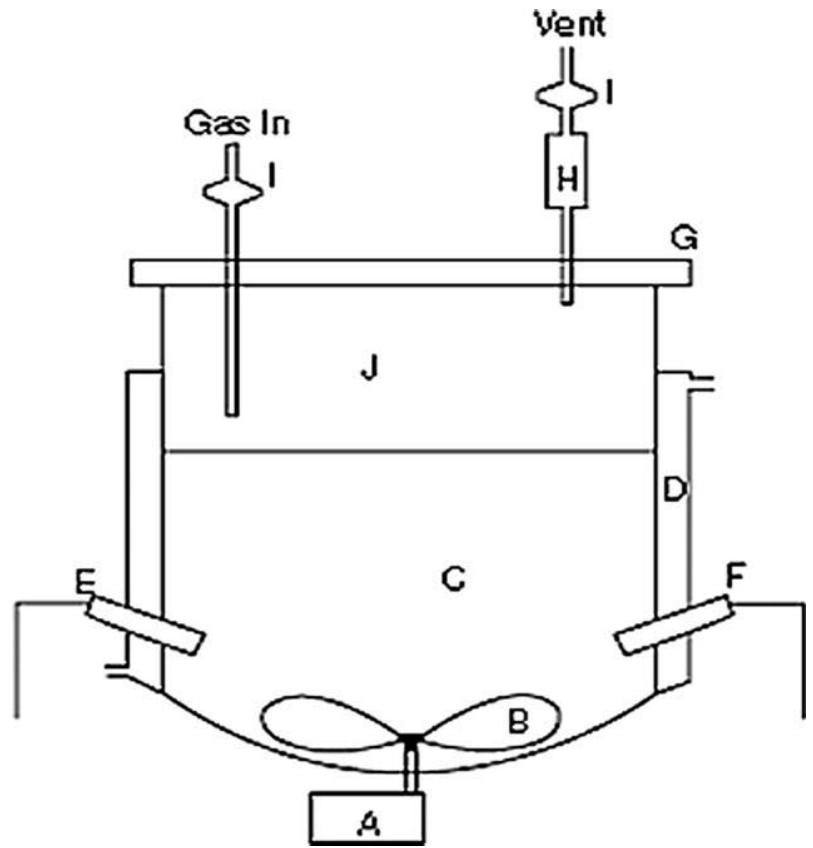

Figure 3. Simplified diagram of a stainless steel stirred tank bioreactor.

(A) Impeller drive, (B) marine impeller, (C) cell suspension, (D) water jacket, (E) $\mathrm{pH}$ probe, (F) DO probe, (G) removable headplate, $(\mathrm{H})$ condenser, (I) gas filter, and $(\mathrm{J})$ headspace. ${ }^{36}$

cell lines. However, the productivities obtained could be further improved if the factors causing stress to the cells could be suppressed, such as shear and bubble damage caused by mechanical agitation and gas sparging. ${ }^{38}$ Consequently, it is one of the main aims in reactor design, with advances being made on the impeller design, to minimize shear damage to cells and consequently improve cell density and $\mathrm{mAb}$ production. ${ }^{39}$

Air-lift reactors. In addition to STRs, airlift reactors (Figure 4) are also widely used for suspension animal cell culture. $^{41,42}$ They can be considered as a type of bubble column, due to mixing being provided by the introduction of gas bubbles at the base of a tall column. ${ }^{43}$ This results in gentler mixing action and suitability for shear-sensitive cells than STR. ${ }^{43}$ Nevertheless, gas sparging is still a concern in terms of cell damage and death, and therefore it is an important factor to regard in reactor design and scale-up. ${ }^{38}$

Other advantages of air-lift bioreactors over STR are the easiest scale-up and the more reliable sterile operation (consequence of the absence of moving parts and mechanical seals). ${ }^{38,44}$ Nevertheless, the air-lift reactor is not as widely used as STR because of less know-how, but also to the limited flexibility in terms of working volume (only up to 2,000 $\mathrm{L}^{44,45}$ ) and limited suitability for microcarrier culture, ${ }^{10}$ which has been considered impractical. ${ }^{46,47}$

Disposable bioreactors. Although stainless steel bioreactors are still the major choice for large-scale production, ${ }^{6}$ in recent years advances have been observed in disposable systems for cell cultivation that have risen the interest in their use at production scale. ${ }^{48}$

Disposable bioreactors can be very advantageous for the manufacturing process in the areas of cleaning, sterilization, set-up, and turn-around time between runs. ${ }^{6,48,49}$ Furthermore, they eliminate the chance of cross-contamination between process runs, ${ }^{49}$ reduce the expensive capital 


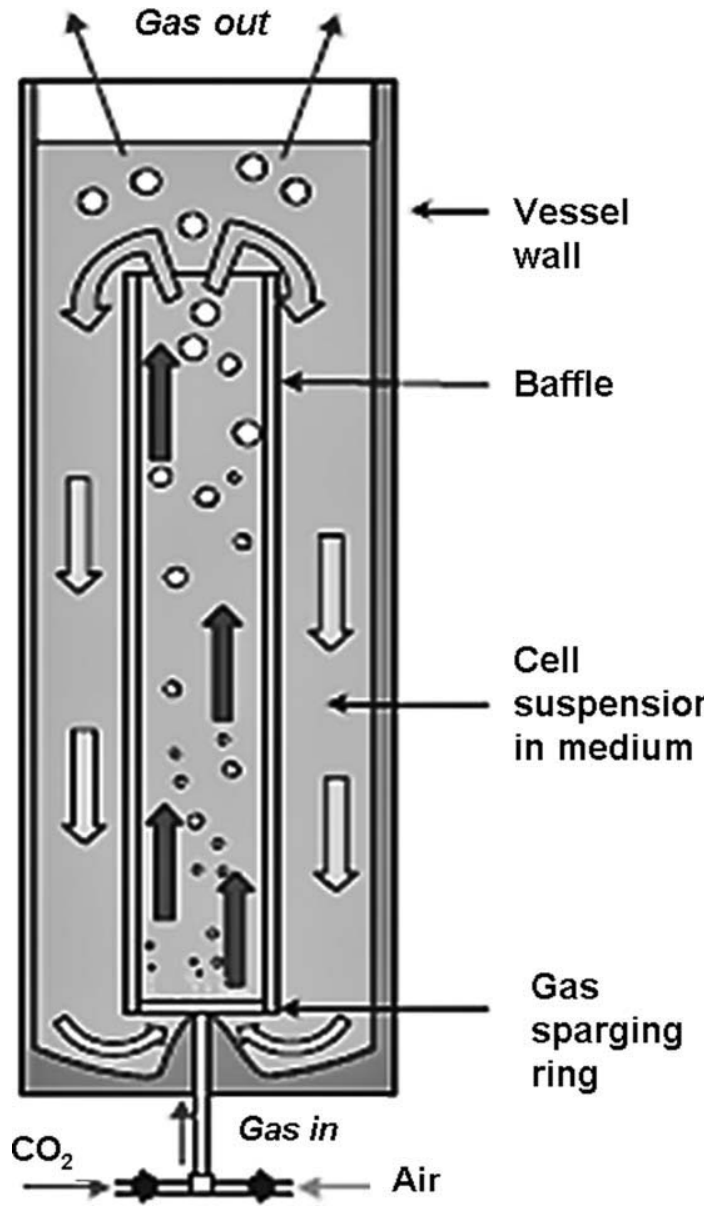

Figure 4. Simplified diagram of an airlift bioreactor. ${ }^{40}$

investment associated with stainless steel bioreactors, ${ }^{6}$ and result in substantial cost savings in initial investment, labor, equipment, facility design, and validation. ${ }^{49}$ Indeed, validation is less complex because of the elimination of the sterilization and cleaning procedures, as well as the use of fewer reusable components that result in fewer items to be tracked. ${ }^{49}$

However, these bioreactors are still limited by their culture volume and, therefore, are mostly used for smaller scale cultivations, for seed culture expansion and for inoculation of the large conventional bioreactors. ${ }^{49,50}$ Nevertheless, bioreactors up to $2,000 \mathrm{~L}$ are currently available, such as the HyClone $^{\circledR}$, Millipore ${ }^{\circledR} \quad\left(\right.$ CellReady $\left.{ }^{\mathrm{TM}}\right)$, or Xcellerex $^{\circledR}$ $\left(\mathrm{XDR}^{\mathrm{TM}}\right)$ single-use bioreactors, that combine the wellknown STR design with the advantages of disposability.

Among the disposable reactors available, the wave bioreactor (Figure 5) is particularly relevant, ${ }^{28,51}$ with strong demand for applications of plant, ${ }^{52}$ insect, ${ }^{28,53}$ and different mammalian cells. ${ }^{28,54-56}$ This bioreactor system, first described by Singh, ${ }^{28}$ consists of a disposable, flexible, sterile plastic bag (CellBag ${ }^{\mathrm{TM}}$ ) that sits on a rocking thermoplatform. ${ }^{28,53,57}$ The cellbags are filled with cell suspension up to half their capacity (from $2 \mathrm{~L}$, for small-scale culture, up to $1,000 \mathrm{~L}$, for large-scale culture) and inflated with air. ${ }^{28,53,57}$ The rocking motion of the cellbag induces undulation to ensure good nutrient distribution, off-bottom suspension, and a greater and constantly renewed surface that increases oxygen transfer without shear damage. ${ }^{28,53,57}$ Oxygen supply is given by headspace aeration, ${ }^{48,53}$ and the headspace can be filled or continuously gassed with the

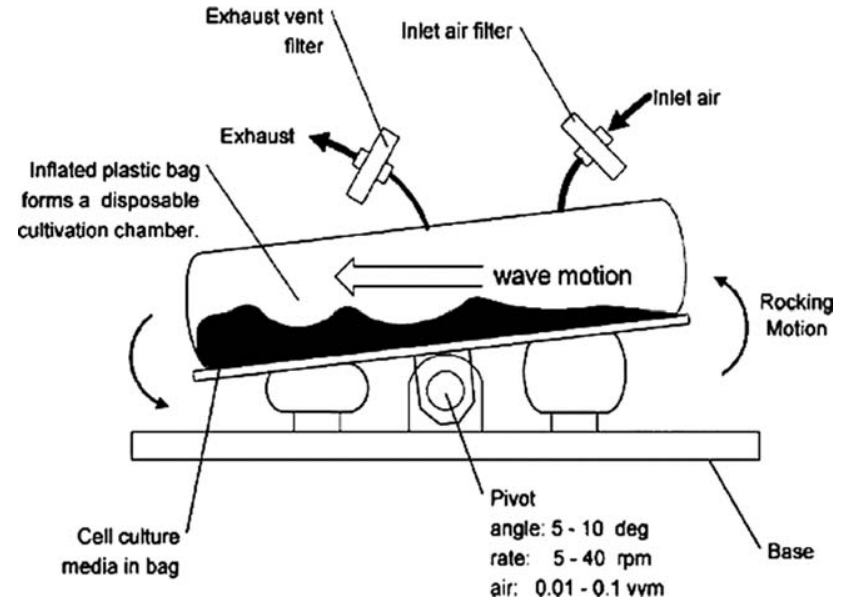
Figure 5. Schematic diagram of the disposable wave
bioreactor.

desired gas mixture. ${ }^{28}$ The system can operate in $\mathrm{CO}_{2}$ incubators or stand-alone in combination with a heater and a $\mathrm{CO}_{2}$ control unit. ${ }^{10,28}$

The wave bioreactor can be valuable for cell/gene therapy applications (primary cell cultivation, rapid expression/ screening of hundreds of genes), ${ }^{28}$ rapid material supply during early stage clinical studies, ${ }^{49}$ process development and clinical manufacturing. ${ }^{57}$ It operates in different culture modes, including perfusion, which can be performed using different cell-retention mechanisms for the high-efficient production of mAbs. ${ }^{58}$

The combined advantages of a fully closed, disposable system with process monitoring capabilities ( $\mathrm{pH}$ and DO) make the wave bioreactor highly attractive over traditional systems for animal cell culture, such as shake flasks and STR ${ }^{57}$ although with limitations in culture volume.

Adherent Culture. Although large-scale production of mAbs by mammalian cells is usually done in suspension culture, continuous efforts are being made to develop high-density adherent cell culture systems. This is a consequence of the adherent growth being the natural state for mammalian cells, ${ }^{4}$ with problems related to suspension culture, such as sensitivity to hydrodynamic shear forces ${ }^{59,60}$ and time-consuming processes of adaptation, ${ }^{61,62}$ not being an issue in the adherent cultures.

However, attachment-dependent cell culture has, as mentioned earlier, the major limitation of low surface-to-volume ratio that results in low cell densities. Therefore, to scale-up these cultures with higher cell densities, it is important to maximize the surface-to-volume ratio. ${ }^{9,11}$ On account of that, many immobilization systems/bioreactors have been developed, where cells are usually immobilized on/inside particles that are suspended in culture medium. ${ }^{63}$ The most wellknown system for culture of adherent cells is microcarrier culture, ${ }^{64,65}$ which can be performed in different bioreactors, with STR being the most common. ${ }^{66}$ Other immobilization systems include small beads of different materials ${ }^{67}$ (agarose, ${ }^{68}$ gelatin and alginate ${ }^{67,69}$ ), gel particles $\left(\right.$ collagen ${ }^{70}$ ), membranes, ${ }^{71-73}$ and fibers. ${ }^{74-77}$

All these systems are ideal for perfusion culture, ${ }^{11}$ which increases cell concentration in the reactor $\left(10^{7}-10^{8}\right.$ cells $\left./ \mathrm{mL}\right)$ and extends the productive lifetime of cells, ${ }^{60,74}$ resulting in increased levels of $\mathrm{mAb}$ productivity when compared with suspension culture. ${ }^{60,74}$ Furthermore, immobilized cell 
Table 2. Properties of the Main Commercially Available Microcarriers (Adapted from Malda and Frondoza ${ }^{84}$ )

\begin{tabular}{|c|c|c|c|c|c|c|}
\hline Material & Name & Size $(\mu \mathrm{m})$ & Surface Area $\left(\mathrm{cm}^{2} / \mathrm{g}\right)$ & Density $(\mathrm{g} / \mathrm{ml})$ & Porosity & Manufacturer \\
\hline \multirow[t]{3}{*}{ Dextran } & Cytodex 1 & $147-248$ & 4,400 & 1.03 & Micro & Amersham Biosciences, Sweden \\
\hline & Cytodex 2 & $135-200$ & 3,300 & 1.04 & Micro & Amersham Biosciences, Sweden \\
\hline & Hillex & $150-210$ & 350 & 1.10 & Micro & SoloHill, USA \\
\hline \multirow[t]{4}{*}{ Plastic } & Plastic coated & $150-210$ & 380 & $1.02-1.04$ & Micro & SoloHill, USA \\
\hline & PlasticPlus coated & $150-210$ & 380 & $1.02-1.04$ & Micro & SoloHill, USA \\
\hline & 2D MicroHex & 125 & 760 & 1.05 & Micro & Nunc, Denmark \\
\hline & Cytoline 2 & $400-2500$ & $>1,000$ & 1.03 & Macro & Amersham Biosciences, Sweden \\
\hline Glass & Glass-coated & $150-210$ & 380 & $1.02-1.04$ & Micro & SoloHill, USA \\
\hline Cellulose & Cytopore 1 & $200-280$ & $\approx 1,200$ & 1.03 & Macro & Amersham Biosciences, Sweden \\
\hline \multirow[t]{2}{*}{ Gelatin } & Cultispher G & $130-380$ & Not available & 1.04 & Macro & Percell Biolitica, Sweden \\
\hline & Cultispher S & $130-380$ & Not available & 1.04 & Macro & Percell Biolitica, Sweden \\
\hline \multirow[t]{2}{*}{ Collagen } & Cytodex 3 & $141-211$ & 2,700 & 1.04 & Micro & Amersham Biosciences, Sweden \\
\hline & Cellagen & $100-400$ & Not available & Not available & Macro & MP Biomedicals, USA \\
\hline
\end{tabular}

reactors have other advantages such as simplifying downstream processing because of cell retention, ${ }^{78}$ which provides cell-free products, ${ }^{60,74}$ creating a favorable microenvironment for cell growth and mAb production. ${ }^{60,78}$ However, these bioreactors still have limitations that result in a problematic long-term use and scale-up. For example, in bioreactors that use beads, destruction of the beads can occur with cell leaking and washout, resulting in declined $\mathrm{mAb}$ production over time. ${ }^{77}$ In membrane and fiber bioreactors, cell degeneration and accumulation of nonviable cells over longterm operation occurs, with biomass build-up, resulting in poor mass transfer. ${ }^{79}$

The particular advantages and limitations of each of the main immobilization systems used are reviewed next.

Microcarrier systems. The development of microcarrier cultures was a major breakthrough for anchorage-dependent cells. ${ }^{80}$ Microcarriers are microscopic particles that are easily maintained in suspension in liquid medium, providing a pseudo-suspension culture for anchorage-dependent cells. ${ }^{4,81}$ They increase the surface area available for cell adhesion and growth, allowing high cell density and productivity. ${ }^{82,83}$

Microcarrier characteristics, such as size, density, and surface charge, are important for their applicability in industrial technologies. ${ }^{10,11}$ They should be small to maximize growth surface area, nontoxic, autoclavable, suitable for microscopic monitoring of cell growth and have densities that allow them to be easily kept in suspension, as well as good adhesion properties and high batch-to-batch consistence. ${ }^{10,11}$ To provide such features, several materials have been tested for microcarrier construction, including dextran, plastic, gelatin, glass, collagen, silicone, and cellulose. ${ }^{10,11}$

Consequently, a variety of microcarriers are available (see Table 2 for a selection of commercially available microcarriers and their main characteristics), and the choice should be made according to the cell line and the purpose of the culture. ${ }^{11}$ Generally, microcarriers can be classified into micro- and macroporous. The original microporous carriers (i.e., Cytodex 1, 2, and 3) have a small pore size that does not allow cells to colonize the interior and, therefore, are used only for external surface attachment. ${ }^{11}$ On the other hand, macroporous carriers (i.e., Cytopore, Cytoline, and Cultisphere) contain open channels, large enough for cells to enter and continue growing, within each bead, providing an increased surface area in comparison to microporous carriers. ${ }^{11}$ Consequently, the maximum cell density and productivity achieved is improved. ${ }^{10}$ Furthermore, macroporous carriers may provide protection to shear-sensitive cells ${ }^{11,85}$ and are also suitable for the propagation of suspended cells that are entrapped in the porous. ${ }^{10}$
To establish an efficient process of microcarrier culture, the full colonization of the available surface should be assured, ${ }^{11,86}$ limiting the number of unoccupied beads at the end of the culture, and achieving a higher cell yield. In processes where detachment of cells from microcarriers is needed, proteolytic enzymes can be used. However, for the production of secreted cell products, as mAbs, this is usually unnecessary. ${ }^{11}$

Suspensions of microcarriers are usually maintained in spinner flasks for scale-up to large-scale bioreactors. ${ }^{11}$ Scaleup of microcarrier cultures is easily accomplished by simply adding new microcarriers into an existing culture, in larger reactors. ${ }^{10,11}$ Cells then begin to colonize the new microcarriers, by bead-to-bead $\operatorname{transfer}^{11,87}$ or, more commonly, by cell detachment from confluent microcarrier surfaces, which will occur in a low calcium medium or by a change of $\mathrm{pH}$ for some cell lines, or by the use of a cocktail of trypsin and ethilenediamine tetra acetic acid (EDTA) in other cases. ${ }^{10,11}$

STR is the most predominant bioreactor used for microcarrier culture..$^{9,88,89}$ The density of microcarriers used in this reactor differs with the mode of culture, with the higher densities being used under fed-batch and perfusion modes allowing increased cell concentrations (more than $10^{7}$ cells/ $\mathrm{mL}$ ) to be achieved. ${ }^{10,90}$ Perfusion is, indeed, the most used operation mode for adherent culture with microcarriers in STR. ${ }^{9,88}$ Retention of the microcarriers can be easily and reliably achieved with spinfilters ${ }^{91,92}$ or other simpler means such as stagnant zones. ${ }^{93}$ This is an advantage over suspension cultures in STR, where cell retention is harder to achieve and problems such as filter fouling or incomplete cell retention have been reported. Nevertheless, problems related to agitation have still been encountered. To achieve a good oxygen supply, certain levels of agitation are necessary. However, cells adhered to the microcarriers are sensitive to overagitation and can be detached above critical stirrer rates. ${ }^{92,94}$ Furthermore, entrapment of microcarriers in foam layers generated by direct sparging and the consequent cell damage has also been observed. ${ }^{95}$

Fluidized bed bioreactors use porous microcarriers with a specific gravity $(>1.6)$ that allows them to stay suspended in a high-velocity upward-fluid flow of culture medium. ${ }^{10}$ In the initial design, this fluidized bed was contained in a column-type bioreactor that was connected to an external recirculation loop, where a gas exchanger, sensors, heating elements, and a circulation pump were located. ${ }^{10}$ The major disadvantage of this reactor was the generation of an oxygen gradient along the axis of the column. This limitation can be overcome by the integration of a membrane oxygenation module directly into the fluidized bed ${ }^{96,97}$ or by the 


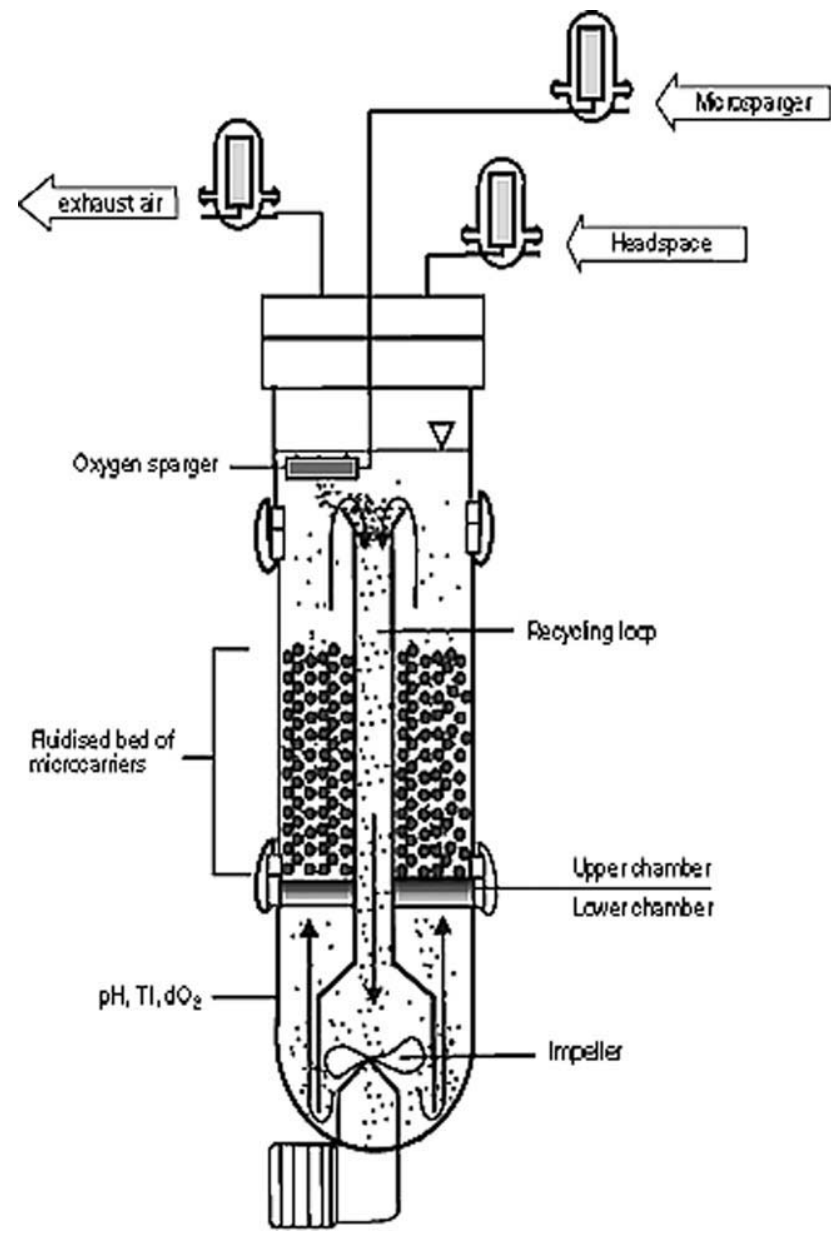

Figure 6. Schematic diagram of the modular fluidized bed bioreactor Cytopilot ${ }^{\mathrm{TM}}$ (www6.gelifesciences.com).

integration of an in-line gasification tube module. ${ }^{98}$ This last fluidized bed bioreactor (Figure 6) has an improved oxygenation, resulting in its current use in biotech industry for large-scale production of proteins for research and medical applications. ${ }^{10}$ However, the available working volumes are still very limited. ${ }^{10}$

Concerning disposable bioreactors, particularly wave, little has been reported about its application for microcarrier cultures, ${ }^{99}$ particularly for mAb production. Nevertheless, the few studies performed, involving vaccine, ${ }^{48,54}$ adenovirus, ${ }^{51}$ and recombinant protein ${ }^{51}$ production, have shown successful results on the use of wave for anchorage-dependent culture using microcarriers.

Membrane and fiber bioreactors. Apart from the systems using suspended microcarriers, other alternative bioreactors and matrices for anchorage-dependent cell culture have been tested.

Hollow fiber bioreactors (HFB, Figure 7) have been extensively studied for $\mathrm{mAb}$ production, ${ }^{100,101}$ usually in perfusion mode. ${ }^{100}$ These systems try to mimic the in vivo mammalian cell environment. For that, cells immobilized at high density are perfused via thousands of capillaries made from ultrafiltration or microfiltration (semipermeable) membranes. The culture medium contained in a reservoir circulates within the capillaries by the action of a pump, bringing oxygen and nutrients to the cells, and removing the waste products, before returning to the reservoir for recirculation. ${ }^{102,103}$ The

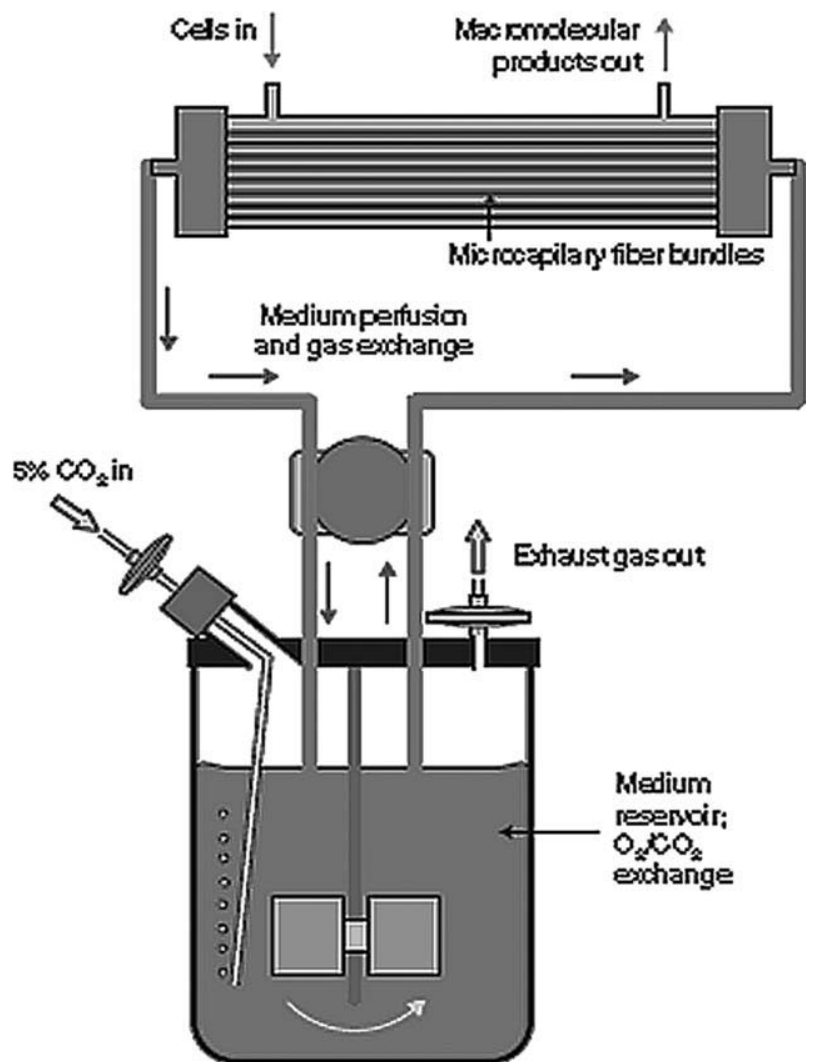

Figure 7. Schematic diagram of a hollow fiber bioreactor. ${ }^{40}$

oxygenation and $\mathrm{pH}$ control is achieved by a gas exchange unit. $^{102}$

The HFB systems generally achieve high cell densities with high $\mathrm{mAb}$ volumetric productivities, consequence of the use of semipermeable membranes that retain the secreted product in the cell compartment, concentrating the product before harvest. ${ }^{74,100}$ This results in products free from medium-derived contaminants, ${ }^{102}$ but with more contamination with dead cells and cell debris, which may put high demands on the purification process. ${ }^{74}$ The accumulation of dead cells over time may also result in relatively short operation life. ${ }^{74}$

The capillary membrane separation between the cells and the main medium flow provides a low shear environment, which is an advantage over the typical STR system. ${ }^{100,102}$ However, HFBs are difficult to scale up, ${ }^{74}$ the large-scale units are expensive, prone to membrane fouling, and have many operation difficulties (mechanical failures and improper feed controls). This may result in low cell viability, process instability, and variable product quality. ${ }^{101,104}$

Fixed or packed bed reactors (FBR) are a widely used alternative bioreactor technology for perfusion culture of immobilized mammalian cells. These reactors are typically composed of a packed bed that supports cells immobilized on or within carriers, a gas exchanger, and a medium reservoir that is used to recirculate the oxygenated nutrient medium through the bed. ${ }^{105,106}$ Therefore, cells are retained in the fixed-bed matrix and the spent medium containing the product that returns to the reservoir can be harvested in batch or continuous mode. ${ }^{74,102}$

FBR can be divided in two major designs (Figure 8): one where the packed-bed compartment is external to the medium reservoir, and the other where it is contained 


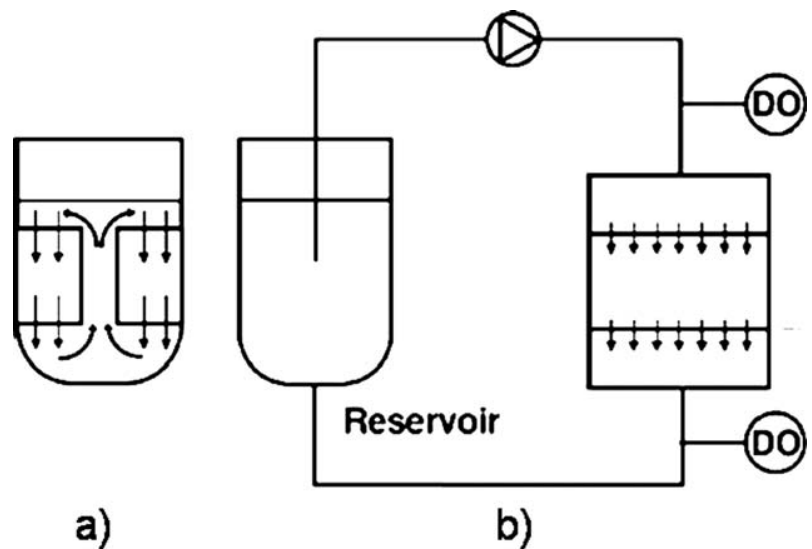

Figure 8. Schematic representation of a fixed bed bioreactor with (a) external and (b) internal recirculation of medium (modified from $^{104}$ ).

within. ${ }^{77,107}$ Additionally, the medium flow through the bed may be parallel to its longitudinal axis or radial. ${ }^{74}$

Several matrices for cell immobilization have been tested. The initial solid glass beads for growing cells as monolayers ${ }^{108}$ were abandoned because of low specific surface-tovolume ratio that resulted in limited cell densities. ${ }^{74}$ This led to the introduction of porous glass spheres that provided higher specific surface, increasing cell densities. ${ }^{106}$ However, the relatively low internal porosity of these spheres posed some limitations to oxygen diffusion within the carriers. ${ }^{74}$ Therefore, the next generation of packing materials has higher internal porosities, and includes glass fibers, ${ }^{76}$ ceramic matrix, ${ }^{109}$ nonwoven fibers made of polydegradable polymers such as polyglycolic acid (PGA) and polylactic acid (PLA), ${ }^{110}$ and non-woven polyester fibrous matrices. ${ }^{11}$ Systems with these carriers achieve high cell densities and productivities, ${ }^{112,113}$ showing the great potential of FBR for commercial use. ${ }^{114}$ This is mainly due to their characteristics of high porosity and high specific surface area for cell adhesion, good mass-transfer efficiency, relatively low pressure drop and shear rates, ease of operation and scale up, and low costs. ${ }^{7,107}$ The low shear rates observed in these bioreactors favor the application of serum- or protein-free media. ${ }^{115}$ Furthermore, the retention of cells in the bioreactor reduces product contamination with cell-derived components, facilitating the downstream processing. ${ }^{102}$ Nevertheless, these systems still have some limitations that need to be surpassed, like the severe clogging and channeling over long-term use, ${ }^{60}$ the heterogeneity that can be observed (formation of concentration and cell gradients), ${ }^{102}$ and still some oxygen transfer limitations. ${ }^{116}$ Indeed, these last two limitations are a major drawback to further scale-up of the FBR systems, because of the maximum packed-bed depth of $\sim 30 \mathrm{~cm}$ they impose. The bed diameter is also limited $(\sim 2 \mathrm{~m})$ because of the difficulty of maintaining a uniform distribution of nutrients over the bed. Consequently, the total volume of the bioreactor becomes restricted, with the maximum FBRs volume reported being of $30 \mathrm{~L} .^{105}$

A derivation of the fixed bed reactor consists of a dialysis bioreactor with radial-flow fixed bed. In this reactor, the two chambers (macroporous carriers-containing and medium-containing) are separated by a cylindrical membrane. The aeration is done in the outer chamber containing the medium that radially flows through the membrane and the cells in the inner chamber, by induction of a centrifugal pump. ${ }^{117,118}$

\section{Modes of operation}

Bioreactors can operate in different modes of culture, with the following being the commonly mentioned in literature: batch, fed-batch, continuous culture without cell retention (chemostat or cytostat), and continuous culture with cell retention (perfusion). ${ }^{10,119}$ The choice of the best mode of operation depends on the application for which it is intended.

Batch Culture. Batch culture is a simple and reliable process, and therefore, the method of choice for many industrial applications. ${ }^{49,120}$ In this mode of operation, the bioreactor is initially charged/inoculated with cells and medium, ${ }^{11}$ and the cells are allowed to reach a determined density and product concentration. $^{49}$ At this point, the cell supernatant is collected $^{49}$ and the product of interest recovered. The scale-up to larger volumes is simple and basically consists on diluting the content of a bioreactor into 5-20 vol of fresh medium kept prewarmed in a larger reactor. ${ }^{4}$

As no additions or withdrawals are performed during batch culture, nutrient concentration will gradually decrease, whereas waste product concentration increases, leading to a gradually deteriorating environment for cell growth. ${ }^{11}$ Therefore, the maximum cell density that is possible to reach (usually about $10^{6}$ cells $/ \mathrm{mL}$ ) is dictated by nutrient limitation (glucose, glutamine), waste product inhibition (ammonia, lactate, $\left.\mathrm{CO}_{2}\right),{ }^{10,11,121}$ or the complete cover of the available growth surface (for anchorage-dependent cells). ${ }^{11}$ This contributes for the major limitation of batch culture-the reduced cell yield that is possible to attain, which ultimately results in reduced product concentrations. This limitation can only be surpassed by nutrient supply and/or removal of waste products, ${ }^{11}$ as it is attempted in other culture modes.

The time of harvest in batch culture is based on the kinetics of product formation, ${ }^{122,123}$ that is, if the product formation is growth or nongrowth associated. In the first case, the specific productivity increases with increasing growth rate and ceases when the culture is entering stationary phase, whereas for the latter, product formation increases with decreasing growth rate or is only observed during stationary phase. ${ }^{10}$ However, the quality of the product should also be an aspect to consider when establishing the time of harvest, because the continuously changing (degradative) composition of the culture medium can affect the quality of the earlier synthesized product. ${ }^{4}$

A derivation of batch mode of operation is the repeated batch culture (batch-refeed), where a fraction of the cell suspension is left in the bioreactor when the culture is harvested and fresh medium is added for a new batch cycle. ${ }^{4,10}$ In this operation, it is critical to assure a high viability of the remaining cell suspension and to optimize the time to initiate the new batch. ${ }^{10}$

Indeed, basic batch suspension processes have the tendency to become less common, because waste accumulation and nutrient fluctuations can be reduced using nutrient feeding strategies that allow higher cell densities and productivities. $^{9}$ Although batch-refeed is the simplest of these strategies, other more efficient modes are also being used, as fed-batch and perfusion.

Fed-Batch Culture. In fed-batch cultures, a controlled nutrient feeding is performed during the course of the culture, ${ }^{11}$ in an attempt to increase the culture longevity (particularly important in the production of growth-associated products), ${ }^{124,125}$ cell yield, ${ }^{11}$ and overall productivity. ${ }^{47}$ 
Nutrient feeding strategies include partial medium changes at regular intervals and the addition of specific nutrients at critical stages of the culture. ${ }^{11,125}$ For this, the limiting nutrients should be identified, so that the correct concentration of a specific nutrient is added at precise intervals. ${ }^{11,124}$ It is therefore implied that a better understanding of the effects that culture conditions have on cell viability and antibody production is needed to establish the essential conditions during a fed-batch operation, aiming for the maximization of product formation. ${ }^{125}$

However, although fed-batch strategies can alleviate the limiting effects of nutrient depletion, the accumulation of waste products to growth-inhibitory concentrations is not avoided/controlled. ${ }^{11}$ Nevertheless, the fed-batch process is often used because of its scalability, ease of operation, and high volumetric productivity. 6,125

Continuous Culture. A continuous culture consists of an open system with continuous feed of fresh medium and removal of spent medium. ${ }^{11}$ This allows cell growth to proceed for longer periods than in a batch or fed-batch culture. This continuous culture can be divided in two main types: chemostat culture and perfusion culture. ${ }^{11}$

In chemostat culture, cells are removed continuously from the bioreactor with the spent medium. ${ }^{126}$ Growth is controlled by the flow rate of fresh medium, expressed as dilution rate (medium flow rate divided by the culture volume), with common values of $0.2-1.0 \mathrm{vol} / \mathrm{day}$ (proportion of cell culture volume replaced in 1 day) for mammalian cells. ${ }^{11}$ When the cell growth rate is equal to the dilution rate, a steady state of equilibrium is reached, where concentrations of cells, nutrients, and products are constant. ${ }^{11}$ These conditions of steady state are always restored if a change occurs, because of the self-regulation of the chemostat system. For example, a temporary decrease in cell concentration will cause a corresponding increase in the growth rate. ${ }^{11}$ In perfusion culture, cells are retained in the bioreactor (e.g., by centrifugation, ${ }^{127}$ internal and external spin filters, ${ }^{128,129}$ or hollow fiber modules ${ }^{130,131}$ ), whereas the spent medium is continuously replaced with a fresh supply. ${ }^{63,132}$ The continuous supply of nutrients and removal of waste products, as well as cell recycle, results in increased longevity, improved cell density ( $>10^{7}$ cells $/ \mathrm{mL}$ ), and, consequently, higher volumetric productivity. ${ }^{130,132}$ The residence time of the product in the culture environment is also reduced, which results in improved product quality. ${ }^{132,133}$ For large-scale production, this system appears to be one of the most advantageous.

\section{Process Monitoring}

Mammalian cell cultures performed in bioreactors allow the production of mAbs in large-scale quantities. However, this production can be further maximized using different strategies, such as nutrient optimization, feeding, cell engineering, or manipulation of the cellular environment. ${ }^{134}$ Among these, the most common practice consists on the optimization of bioreactor culture conditions, because it represents an economical and reliable way to ensure optimal productivity. ${ }^{134}$ For this, the culture parameters more relevant for cell growth and productivity need to be identified, and their individual and interrelated effects better understood. Furthermore, methods and technologies for monitoring and control the physicochemical environment in which cells are exposed are essential to achieve productivity improvements in bioreactors. ${ }^{6}$

\section{Parameters}

In the optimization of productivity, a balance between cell growth and mAb production ${ }^{6}$ needs to be achieved, because the conditions that are optimal for a specific mAb may not be the same for other. Nevertheless, process parameters, such as temperature, $\mathrm{pH}$, osmolarity, $\mathrm{DO}, \mathrm{CO}_{2}$, and nutrient and metabolites concentration, have been shown to affect cell performance $^{135}$ and are, therefore, generally seen as the most relevant for optimization of production in mammalian cultures.

Temperature. Temperature is one of the most critical and more studied variables to monitor for maintenance of healthy cell cultures. ${ }^{136,137}$ Although the ideal growth temperature for most mammalian cells is $37^{\circ} \mathrm{C}$ (the body temperature), it has been shown that this may not be the best temperature for recombinant protein $/ \mathrm{mAb}$ production. Indeed, some studies $^{138,139}$ have demonstrated that a lower temperature (around $30-35^{\circ} \mathrm{C}$ ) may have a positive outcome in terms of $\mathrm{mAb}$ specific productivity, while maintaining or improving product quality. ${ }^{135}$ However, the increase of the specific productivity does not often results in improved volumetric productivity, because of the negative effects that low temperatures have in the cell growth rate. ${ }^{140}$ Therefore, the most advantageous temperature strategy may be culturing cells at $37^{\circ} \mathrm{C}$ until a high cell density is reached and then shifting to lower temperatures to achieve higher product titers. $^{141,142}$

$p H$. Along with temperature, $\mathrm{pH}$ is considered to be one of the most critical parameters for mammalian cell culture, because of the severe effects its variation can cause to cells. ${ }^{10,143}$ Indeed, even small variations of $\mathrm{pH}(0.1)$ can have impact on cell growth, productivity, cell metabolism, and protein glycosylation. ${ }^{144,145}$ Furthermore, optimal pHs for specific growth rate and specific protein production may not be necessarily the same. ${ }^{145}$ In bioreactors, $\mathrm{pH}$ should ideally be near 7.4 at the beginning of the culture and not fall below 7.0 during culture, ${ }^{10,146}$ although values set between 6.5 and 7.8 are usually acceptable. ${ }^{6}$ The highest values of $\mathrm{pH}$ are preferred for starting the culture because they favor cell growth. ${ }^{6}$ However, they also increase the anaerobic cell metabolism that leads to the accumulation of metabolites (particularly lactate). Therefore, after reaching a desired cell density, $\mathrm{pH}$ is usually shifted to a lower value that, although halting cell growth, ${ }^{45,146,147}$ will improve mAb production. $^{6,147}$

Maintenance of $\mathrm{pH}$ stability in culture is affected by different factors, including buffer capacity and type, ${ }^{10,146}$ bioreactor headspace, and glucose concentration. ${ }^{146}$ Mammalian cell culture medium is prepared with a buffer system to control $\mathrm{pH}$ variations, and it usually consists on the $\mathrm{CO}_{2}$ bicarbonate system. ${ }^{146}$ This system requires the addition of $\mathrm{CO}_{2}$ to the culture vessel headspace or the addition of bicarbonate base. ${ }^{146}$ Nevertheless, other buffer systems can be used to improve buffering and $\mathrm{pH}$ stability, such as the zwitterionic buffer $^{148}$ (i.e., Hepes), that can be used alone or in combination with bicarbonate, or specialist media such as Leibovitz's L-15. ${ }^{149}$

Because the normal buffer system needs a certain level of $\mathrm{CO}_{2}(5 \%)$ to maintain a stable $\mathrm{pH}$, it is important that the culture vessel has a large headspace or an open system with continuous flow of air (required in large bioreactors). This will assure that $\mathrm{CO}_{2}$ generated during cell growth adequately diffuses from the medium, without build-up and consequent decrease in $\mathrm{pH}^{146}$ 
In addition, glucose concentration in the medium also affects $\mathrm{pH}$. Glucose is metabolized by cells at a greater rate than it is needed and results in the formation of toxic metabolites (pyruvic and lactic acids) that lower $\mathrm{pH}$ to nonphysiological levels. ${ }^{146}$ To avoid the fast build-up of metabolites and deterioration of the medium, glucose should be added in small concentrations (no more than $2 \mathrm{~g} / \mathrm{L}$ ) to the medium during culture. Other approach is to replace glucose by other carbon sources, such as galactose or fructose, which significantly reduces formation of lactic acid, but also results in slower cell growth. Nevertheless, in large bioreactors, a $\mathrm{pH}$ control system is usually essential. ${ }^{146}$

Osmolarity. Osmolarity strongly influences mAb production, cell growth, and death rates, as well as the duration of exponential growth. ${ }^{124}$ Increases in osmolarity are observed because of additions of base (to control $\mathrm{pH}$ ) or of glucose or medium concentrates to the culture. ${ }^{124,150}$ The resultant high levels of osmolarity cause decreased growth rates and cell concentrations. However, within a certain range (300-400 $\mathrm{mOsm} / \mathrm{kg}$ ), the osmolarity increase can be beneficial. Indeed, at this range, the negative consequences in cell growth can be compensated with increases on the specific mAb production rate, resulting in a higher final antibody concentration. ${ }^{151}$ For this reason, hyperosmolarity is sometimes described as one alternative to improve mAb production, with the advantage of being more economical than others. ${ }^{152,153}$

Dissolved Oxygen. Mammalian cells require oxygen for the production of energy from organic carbon sources. ${ }^{10,143}$ Therefore, oxygen available for cell use (DO) is an important parameter for mammalian cell culture. The amount of DO in the medium is dependent on a diversity of factors, such as cell growth rate, carbon source, ${ }^{10}$ and specific rate of consumption by the cells, ${ }^{154}$ that leads to a state of dynamic equilibrium of DO. ${ }^{10}$ Although DO may not negatively affect cell growth and production levels within a large range $\left(\mathrm{pO}_{2}\right.$ between 20 and $100 \%$ of air saturation), ${ }^{6,146}$ it can have negative consequences on product quality (glycosylation). 6,155

Furthermore, scale-up represents a problem for guaranteeing correct levels of DO in the culture, because the methods currently available for that purpose cannot assure high cell oxygenation without causing some cell damage (see next section). ${ }^{146}$

Carbon Dioxide. $\mathrm{CO}_{2}$ is known to have an essential role in mammalian cell culture to maintain the culture $\mathrm{pH}$ at the normal optimum range and to regulate many cellular activities. ${ }^{156}$ Therefore, the concentration of $\mathrm{CO}_{2}$ should be maintained at physiological levels (partial pressure of $\sim 50-70$ $\mathrm{mmHg}$ at $\left.37^{\circ} \mathrm{C}^{157}\right) .{ }^{158}$ However, during scale-up in largescale bioreactors, the $\mathrm{CO}_{2}$ partial pressure tends to build up to levels higher than physiological, causing significant problems in mammalian cell culture. ${ }^{159-161}$ In fact, it has been shown that high dissolved $\mathrm{CO}_{2}$ concentrations can have detrimental effects on cell growth, nutrient utilization, product formation (productivity), and product quality. ${ }^{158,162,163}$ These detrimental effects must be carefully considered during optimization of mammalian cell culture process, to achieve higher productivities and better product quality. ${ }^{158,164}$

Nutrient and Metabolites Concentration. Nutrients present in the medium are the support for cell growth, and their exhaustion can jeopardize cell growth rates. ${ }^{146,164}$ Among the nutrients needed for cell culture, glutamine and glucose are considered as the most critical/limiting ones, which is evident from the reduction of cell growth rate that occurs even before these nutrients are totally consumed. ${ }^{146}$ Furthermore, as mentioned earlier, consumption of glucose by cells, especially when present at high concentrations in the medium, is done at a higher rate than necessary. This leads to the rapid accumulation of toxic metabolites (lactate, ammonia) that can inhibit cell growth and/or protein productivity, ${ }^{165}$ as well as affect product's glycosylation. ${ }^{166}$ To avoid this, some attempts have been made, which include reduction of ammonia formation by controlling glutamine concentration, ${ }^{90}$ modification of the energy metabolism by controlling glucose concentration (e.g., by feeding less glucose to the culture but more periodically, in concentrations according to cell needs), ${ }^{165,167,168}$ or replacement of glucose by a slower utilized substrate such as galactose. ${ }^{169}$

Apart from the control of the main nutrients, other compounds may be added to the medium to reach an optimal culture performance. These include growth factors and hormones such as insulin, transferrin, ethanolamine, and selenium. ${ }^{170}$

Glycosylation. Mammalian cell lines are the host of choice for the production of therapeutic mAbs especially because of their ability to perform correct post-translational modifications, particularly glycosylation, which has a major effect on the biological properties of the product (pharmacokinetics, bioactivity, secretion, in vivo clearance, solubility, receptor recognition, and antigenicity). ${ }^{171,172}$ Hence, it is essential to ensure that a consistent glycosylation profile is maintained between batches in the process of production. ${ }^{6,173}$ However, culture conditions, such as temperature, $\mathrm{pH},{ }^{174}$ $\mathrm{DO}, \mathrm{CO}_{2}$, osmolarity, ${ }^{175}$ time of culture, ${ }^{176}$ as well as nutrient and metabolite concentrations, ${ }^{174,175,177}$ have been shown to affect glycosylation. ${ }^{6,178,179}$ Therefore, it is of extreme importance to have a further understanding of the parameters that control protein glycosylation in bioreactors, and to monitor product quality during each step of the optimization, to be able to ensure the quality and consistency needed for biopharmaceutical production. ${ }^{6,171}$

\section{On-line/off-line control}

During bioreactor culture, it is important to assess the culture health. For this, several key parameters are routinely measured, such as $\mathrm{pH}$, DO, dissolved $\mathrm{CO}_{2}$, temperature, nutrients and metabolites concentration, cell density and viability, as well as product concentration and quality. Monitoring these parameters allows the follow-up of culture growth and metabolism, and in case of decline of cell health it helps identifying the cause (starvation, bacterial contamination, or bioreactor equipment failure). To be able to efficiently and timely intervene in the culture to maintain cell health, this monitoring should ideally be performed on-line, in real-time. However, this is currently only possible for some parameters (temperature, $\mathrm{pH}, \mathrm{DO}$, and dissolved $\mathrm{CO}_{2}$ ), whereas others (cell density/viability, nutrient and metabolites concentration, $\mathrm{mAb}$ concentration, and quality) are still analyzed using offline techniques. ${ }^{6}$ Nevertheless, efforts are being made to develop methodologies that will allow the on-line monitoring of such parameters.

Temperature. Temperature is a major player in culture optimization, and as such, instrumentation and strategies developed for its control should be highly accurate $\left(\leq 0.5^{\circ} \mathrm{C}\right.$ is considered adequate $\left.{ }^{180}\right) .{ }^{10}$ The most commonly used instrumentation is the resistance temperature devices (RTDs) 
(usually made of platinum), which combine characteristics of high accuracy, high reproducibility, and fast response time with moderately high costs. With lower costs than RTDs are the thermocouples that, however, give less accurate and stable temperature measurements. ${ }^{10}$

Control of temperature in mammalian cell cultures has been using systems regulating the temperature or flow rate of water in an external water jacket or in internal heating or cooling coils. ${ }^{10}$ Moreover, although in laboratory-scale bioreactors the control can be on-off, in larger bioreactors a more precise control is needed. For this, proportional-integral (PI) or proportional-integral-derivative (PID) control schemes can be applied. ${ }^{181}$

$p H$. $\mathrm{pH}$ monitoring is currently performed on-line, using an autoclavable $\mathrm{pH}$ probe (usually electrochemical probes ${ }^{143}$ ) that feeds a signal that is transformed into an analogue or digital display of the culture $\mathrm{pH}^{146}$ This allows direct and continuous measurements to be taken, providing information on both growth and cellular metabolism, because they are strongly dependent on medium $\mathrm{pH} .{ }^{182,183}$

To control $\mathrm{pH}$, maximum and minimum acceptable $\mathrm{pH}$ values need to be set, so that $\mathrm{pH}$ is maintained within a defined range. ${ }^{146}$ If the culture $\mathrm{pH}$ drifts away from the range established, the system activates pumps that add acid or base to the culture to set it back into the desired values. ${ }^{10,146}$ Though, usually, only base additions are needed (often $\mathrm{KOH}, \mathrm{NaOH}, \mathrm{NaHCO}_{2}$, or $\mathrm{Na}_{2} \mathrm{CO}_{3}{ }^{10}$ ), since cell metabolism results in $\mathrm{pH}$ decrease. ${ }^{10,146}$ Furthermore, the $\mathrm{pH}$ monitoring system also involves control of the gas supply, more particularly, $\mathrm{CO}_{2}$ additions to the medium. If $\mathrm{pH}$ is above the set point, $\mathrm{CO}_{2}$ will be delivered to the culture, but if it is below this value, only air, oxygen, or a mixture of both will be added. ${ }^{146}$ Moreover, $\mathrm{pH}$ control is helped by the buffering capacity of most mammalian cell culture media. ${ }^{10}$

Apart from glass electrodes, other methods have been developed for $\mathrm{pH}$ quantification, such as optical and fiber-optical pH sensors. ${ }^{143,184,185}$ These sensors can be based on conductive polymers, imaging fibers, microparticles and nanospheres, as well as micrometer, submicrometer, and distributed fiber-optic sensors. Other $\mathrm{pH}$ sensors include acidity and alkalinity sensors, $\mathrm{pH}$ sensors with broad dynamic range and linear response, and $\mathrm{CO}_{2}$ and $\mathrm{NH}_{3}$ sensors based on $\mathrm{pH}$ indicators.

Dissolved Oxygen. The direct and continuous monitoring of DO provides important information about growth and cellular metabolism rates. ${ }^{183,186}$ For this, quantification of DO is usually performed amperometrically, using a Clark-type electrode that consists of an electrode covered by a membrane that is selectively permeable to oxygen. ${ }^{187}$ Additionally, a spectrophotometric method based on a colorimetric technique $^{188}$ can be used, which has a sensitivity lower than the amperometric method but still higher than needed for cell culture. ${ }^{10}$ Another alternative is the use of oxygen sensors based on fluorescent quenching of suitable dyes, ${ }^{189,190}$ which show good stability and reversibility. ${ }^{10}$ Actually, optical sensors have been developed for the measurement of oxygen levels in culture. ${ }^{143,185,191}$

To control the oxygen levels in culture, different methods (or a combination) can be used. In smaller cultures, the maintenance of a large headspace volume is extremely important and usually sufficient to assure no oxygen limitation to cells. ${ }^{146}$ In larger reactors, however, other methods need to be used to guarantee adequate oxygen supply. These include sparging, membrane diffusion, medium perfusion, increasing of the partial pressure of oxygen, and increasing of the atmospheric pressure. ${ }^{192}$

Sparging consists of bubbling gas through the cell culture but, although very efficient, it can cause damage to the cell membrane because of the high surface energy of the bubbles. ${ }^{146}$ These negative effects can be minimized by using larger air bubbles, a very low gassing rate or by adding Pluronic F-68 (a shear protectant) to the medium. For its turn, the membrane diffusion method uses tubing of very gas-permeable silicone arranged in the bioreactor to achieve sufficient oxygen diffusion. However, because of the large quantities of tubing required, the method is expensive and inconvenient to use and also difficult to scale-up. ${ }^{146}$

A more advantageous method is the medium perfusion, in which the medium is continuously (or on demand) taken from the culture and passed through an oxygenation chamber before returning to the culture. As the medium is separated from the cells, it can be conveniently sparged to ensure oxygen saturation without damaging cells. ${ }^{146}$

Furthermore, when the bioreactor culture is already advanced, DO concentration can be increased by raising the headspace oxygen pressure $\left(\mathrm{pO}_{2}\right)$ and/or the pressure of the culture (to increase the oxygen solubility and diffusion rate). ${ }^{146}$

Dissolved $\mathrm{CO}_{2}$. Although in mammalian cell culture DO is the parameter most often used for on-line monitoring and feed control, ${ }^{193}$ dissolved $\mathrm{CO}_{2}$ is another component of interest that can be used as an indicative of the cellular metabolism. ${ }^{10} \mathrm{CO}_{2}$ measurements can be performed with offline sensors, but these are limited by the low frequency of data collection (not allowing continuous control) and the need for sampling. ${ }^{157}$ Therefore, attempts to develop in situ $\mathrm{CO}_{2}$ sensors have been made. Commonly, $\mathrm{CO}_{2}$ is quantified in the gas phase using relatively inexpensive infra-red analyzers, which require stable temperature and consistent levels of moisture in the vapor environment. ${ }^{10}$ More recent techniques, for $\mathrm{CO}_{2}$ quantification in the medium, include sensors that use a gas-permeable membrane to separate a bicarbonate buffer from the analyte solution and a glass $\mathrm{pH}$ electrode, ${ }^{194}$ and optic fiber probes that use a $\mathrm{pH}$ sensitive dye and an optical fiber (e.g., the commercialized YSI 8500 sensor). ${ }^{157,195}$ Other alternative methodologies to monitor $\mathrm{CO}_{2}$ include gas chromatography and mass spectrometry, which has a rapid response time and high sensitivity, being one of the most promising techniques. ${ }^{10}$

Cell Density and Viability. The success of a mammalian cell culture is typically evaluated by cell density and viability, because the goal of a culture scale-up process is to maximize the total number of viable cells in the minimal amount of time. ${ }^{196}$ The common practice for the assessment of cell density and viability is to take daily samples from the bioreactor and to perform off-line measurements. The off-line methodologies used can be direct or indirect ${ }^{197}$ and can assess both density and viability or just one of these parameters. For direct measurements, a hematocytometer is commonly used, allowing microscopic cell counting. In conjugation with a dye exclusion test, it becomes possible to simultaneously assess cell viability, based on the concept that viable cells do not take up certain dyes (e.g., trypan blue or erythrocin) in opposition to dead cells. ${ }^{146}$ Automated cell counters are also available for direct assessment of cell growth and viability (e.g., Microcyte, ${ }^{198}$ Nucleocounter, ${ }^{199}$ 
and Guava $\left.\mathrm{PCA}^{200}\right),{ }^{6}$ as well as colorimetric methods 3(4,5-Dimethylthiazol-2-41)-2,5-diphenyltetrazolium bromide (MTT assay). ${ }^{5}$ On the other hand, indirect methodologies for both density and viability analysis are usually based on metabolic activity (glucose or oxygen uptake; lactic, pyruvic acid, or $\mathrm{CO}_{2}$ production) or the expression of a product. $^{146,201}$ Cell density can also be indirectly assessed by total cell mass measurement through total protein or dry weight determination. ${ }^{146}$

The indirect methods are not as accurate as the direct techniques, because the correlations between the specific metabolic rates measured and cell density/viability vary with the growth phase of cells. ${ }^{146,202}$ Nevertheless, these methods can be very useful in situations where cells cannot be sampled, such as most anchorage-dependent cultures, or visually examined. ${ }^{146}$

Off-line measurements of these parameters are the common procedure currently used. However, ideally, the assessment of cell density and viability should be performed on-line, inside the bioreactor, without the need for sampling. This would allow a frequent or even continuous (real-time) monitoring, providing early indications of catastrophic events as contamination or cessation of growth, ${ }^{183}$ and helping to ensure that medium additions to the culture occur at appropriate times. ${ }^{201}$ Strategies for such measurements have been developed and include turbidity, ${ }^{203}$ oxygen uptake rate, dielectric spectroscopy, ${ }^{204}$ near-infrared (NIR) spectroscopy, ${ }^{205}$ capacitance detection $^{204}$ flow injection flow cytometry, ${ }^{206,207}$ optical microscopic imaging, ${ }^{208}$ CEDEX cell counter, ${ }^{201}$ and optical sensors. ${ }^{143}$ However, most of these methods have low sensitivity or are affected by medium debris and are usually unable to measure cell concentrations below $5 \times 10^{5}$ cells $/ \mathrm{mL}$. $^{201}$

Nutrient and Metabolites Concentration. Culture health is strongly dependent on nutrient and metabolite concentrations in the medium. Therefore, efforts have been made to develop methodologies for monitoring these parameters. Because of its importance, glucose and glutamine, as well as their metabolic products (ammonia, lactate, and glutamate) are the main concern in such developments. However, recent evidence suggests that monitoring of a greater number of components in bioreactors may be needed to sustain a health culture. $^{209}$ Indeed, ideally, all or nearly all of the high-level components in a cultivation should be tracked.

Although, currently, nutrient and metabolite monitoring still focus mostly on the main components, with the common practice consisting of taking period samples from the bioreactor and performing off-line analysis, this analysis usually involves high-performance liquid chromatography (HPLC) $)^{6,167,168}$ or the recent and faster ultra-performance liquid chromatography (UPLC) ${ }^{210-212}$ (amino acids), commercially available analyzers such as the YSI analyzer (glucose, lactate, ammonia) $)^{6,167,168,213}$ and enzyme-based or spectrophotometric assay kits (ammonia, glutamine). ${ }^{10,167,168}$

Developments on on-line control include methods of chromatography, enzymatic conversions, flow injection, and optical sensing. ${ }^{214}$ On-line chromatography analysis was the first to be applied, but it requires substantial time for measurements and the periodic removal of samples, implying a risk of bioreactor contamination and loss of some amount of product. ${ }^{10}$ In this sense, enzymatic sensors can be very useful, as they provide rapid measurements from within the bioreactor. ${ }^{10}$ However, these sensors have problems related to the need for frequent recalibrations and for the separation of the enzyme from the bioreactor environment, and therefore, measurements using these enzymatic biosensors are usually performed off-line. ${ }^{10}$

Another technology developed for on-line monitoring is the flow injection analysis (FIA), which uses different detection methods, namely amperometry, potentiometry, fluorescence, chemiluminescence, UV-vis absorbance, or turbidometry. ${ }^{215}$ FIA has a low risk of contamination, is easy to recalibrate, requires small samples, and provides a rapid analysis. ${ }^{10}$ It has been used for measurements of glucose ${ }^{216,217}$ glutamine, ${ }^{216}$ glutamate, ${ }^{188}$ ammonia, ${ }^{218}$ and lactate $^{217}$ concentrations. Though, each FIA sensor can monitor only one analyte and often does not possess enough sensitivity and selectivity. ${ }^{219}$

The need for sampling from the reactor before analysis can be eliminated by the use of spectroscopic methods. They allow real-time monitoring of multiple analytes without sample preparation and in a noninvasive and nondestructive way. ${ }^{10}$ These optical sensors can use visible, UV, or NIR light and have been applied in the measurement of glucose, $^{220-222}$ glutamine, ${ }^{220-222}$ ammonia, ${ }^{220,222}$ lactate, ${ }^{220,222}$ glutamate, ${ }^{222}$ sucrose, ${ }^{223}$ fructose, ${ }^{223}$ maltose, ${ }^{224}$ and asparagines ${ }^{221}$ concentrations.

MAb Concentration. Conventionally, mAb production is quantified using methods as the standard enzyme-linked immunosorbent assay, ${ }^{225}$ Western blot, protein A HPLC, and bioassays. $^{226}$ However, these methods are time-consuming, variable, and require substantial amounts of cell culture samples. ${ }^{26,227}$ Therefore, methods allowing real-time monitoring of $\mathrm{mAb}$ concentration would be extremely useful to accelerate cell line screening and optimization of culture parameters. $^{227}$

For this purpose, the use of fluorescence intensity has been tested, and it has been observed that it allows the screening of a higher number of clones than the conventional assays. This significantly reduces the effort and time spent for screening and improves the chances of identifying high producers. ${ }^{228}$ More recently, a mass spectrometer connected to a bioreactor has been used to quantify multiple proteins in the culture media, ${ }^{229}$ as well as a surface plasmon resonance-based biosensor that allows on-line follow-up of the relative concentration of the protein of interest. ${ }^{226}$ This last method has showed potential to on-line analysis of protein bioactivity. ${ }^{226}$

Furthermore, innovative approaches have been emerging from the nanotechnology field, which will enhance sensitivity to the level of single molecule detection. These include metallic nanostructures (with unique optical properties) for the detection of biomolecule interactions, ${ }^{230,231}$ combination of metallic nanoparticles and nanofilms with fluorescent probes, ${ }^{232,233}$ and combination of metal-enhanced fluorescence and phase modulation fluorometry. ${ }^{227}$

These advances will contribute for the development of compact benchtop or handheld instruments for mAb quantification, similar to those routinely used for glucose monitoring. ${ }^{227}$

Post-Translational Modifications. Post-translational processing is required to obtain a fully biologically active mAb. Among the post-translational modifications, glycosylation is one of the most important, ${ }^{175}$ playing critical roles in protein folding, activity, immunogenicity, and protease sensitivity in vivo. $^{234}$ Several techniques are available to analyze glycosylation of the product obtained from mammalian cell culture. $^{235}$ This analysis is important to ensure quality and 
stability of the product, as well as batch consistency, and can be based on different physical or chemical characteristics of the glycoprotein. ${ }^{10}$ Broadly, four methods can be used: (i) separating the glycoprotein by glycoforms, (ii) determining the glycoprotein monosaccharide content, (iii) cleaving oligosaccharides from the glycoprotein, and (iv) degrading the glycoprotein via peptidases. ${ }^{236}$ To meet FDA requirements of glycoprotein characterization, at least two of these analytical methods need to be performed. ${ }^{10}$ For each of these methods, different techniques can be used, with the more common being electrophoresis, liquid chromatography (LC), mass spectrometry (MS), nuclear magnetic resonance (NMR), and exoglycosidase digestion. ${ }^{10,237,238}$ The choice of the appropriate technique is based on several factors, namely the amount of sample required, cost per sample, desired resolution, and availability of equipment and technical expertise. ${ }^{10}$

For the first method, whole or intact proteins are directly analyzed based on size, charge, affinity, and oligosaccharide content, using sodium dodecyl sulfate polyaceylamide gel electrophoresis (SDS-PAGE), isoelectric focusing polyacrylamide gel electrophoresis (IEF-PAGE), ion exchange chromatography (IEC), 2D-PAGE, Western blots, capillary electrophoresis (CE), matrix-assisted laser desorption ionization mass spectrometry (MALDI-MS), and exoglycosidase digestion. ${ }^{10}$ This method is relatively easy, fast, and inexpensive, but only allows a low level of resolution for the glycosylation analysis. ${ }^{10,238}$ For these reasons, this analysis is commonly used only to assess batch consistency of protein glycosylation. $^{239}$

The second method involves the analysis of monosaccharides that are obtained directly from an intact glycoprotein or glycopeptides pool. ${ }^{10}$ Such analysis can be performed by different analytical techniques as fluorophore-assisted carbohydrate electrophoresis (FACE), HPLC, ${ }^{240}$ MALDI-MS, and NMR, which give more detailed information about identity, composition, anomericity, and linkages of the monosaccharides. ${ }^{10}$

In the third method, oligosaccharides are obtained from glycoproteins and glycopeptides (chemically or enzymatically $)^{239,241}$ and analyzed, with varied degrees of accuracy, by FACE, CE, HPLC, fast-atom bombardment mass spectrometry (FAB-MS), electrospray mass spectrometry (ESMS), MALDI-MS, liquid chromatography mass spectrometry (LC-MS), ${ }^{238} \mathrm{NMR}$, or exoglycosidase digestion. ${ }^{10}$ Information about mass, composition, linkages, and sequence can be obtained, ${ }^{10}$ with LC-based methods being the most accurate.

The last method also allows the analysis of glycopeptides that are obtained from the proteolytic digestion of the glycoprotein. For this, the techniques used are IEF-PAGE, CE, HPLC, FAB-MS, ES-MS, MALDI-MS, LC-MS, and exoglycosidase digestion. ${ }^{10}$

Besides glycosylation, other post-translational modifications are important to maintain the structure and function of a mAb molecule, such as deamidation, isomerization, oxidation, proteolysis, and aggregation. ${ }^{174,242}$ The methods typically used to analyze these modifications include cationexchange chromatography $(\mathrm{CEX}),{ }^{243}$ isoelectric focusing (IEF), ${ }^{243}$ hydrophobic interaction chromatography (HIC), ${ }^{244}$ $\mathrm{CE},{ }^{245} \mathrm{MS}^{243}$ and reverse-phase HPLC-MS (RPLC-MS). ${ }^{246}$

\section{Scale-Up}

The aim of process scale-up is to obtain larger quantities of the product, maintaining high levels of productivity and product quality. ${ }^{247}$ For this, both physical (configuration of the bioreactor) and chemical requirements of cells have to be satisfied, so that cells are kept in the proper physiological environment. However, satisfying these requirements during scale-up to industrial level is a challenging process, since the many different factors involved interconnect and sometimes compete between themselves. ${ }^{60,247,248}$

Parameters such as temperature, DO, and $\mathrm{pH}$ are all volume independent and, therefore, are set for larger bioreactors at the same levels as for smaller bioreactors. ${ }^{248}$ On the other hand, the total air flow rate as well as $\mathrm{CO}_{2}$ and oxygen flow rates have to be changed according to the culture working volume, to maintain a normalized volumetric flow rate. This is simply obtained by dividing the total air flow rate by the volume. $^{248}$ However, because of problems related with low mixing rates, accumulation of $\mathrm{CO}_{2}$ becomes a recurrent issue in scale-up, ${ }^{160,161}$ because it has been shown to cause inhibitory effects on cell growth and antibody production ${ }^{152,160,162}$ and quality. ${ }^{159}$

Indeed, the agitation rate is one of the most critical ${ }^{249}$ and difficult parameters to scale-up, because it needs to provide sufficient mixing (for good mass transfer and homogeneity) in the larger bioreactors and, simultaneously, not cause too much stress and damage to the cells. ${ }^{45,248,249}$ A good balance is hard to attain, and usually $\mathrm{pH}$ and nutrient gradients are present in large-scale bioreactors because of poor mixing, ${ }^{250,251}$ which result in reduced cell growth and antibody production. $^{252}$

Moreover, changes on the agitation speed may impact other parameters that should be maintained during scale-up, such as the critical ${ }^{253}$ oxygen transfer coefficient. ${ }^{248}$ Therefore, this will imply the adjustment of other conditions that would otherwise be simple to scale-up.

During scale-up, nutrient limitation is another factor to consider, with feed additions needing some adjustments. Although the schedule of feed additions is maintained across scales, the feed volume and rate need to be changed according to the volume. ${ }^{248}$ As the feed stock is usually more concentrated for large-scale production, because of ease of preparation, handling, and storage, this concentration factor should also be considered in the scale-up. ${ }^{248}$ Furthermore, in large-scale bioreactors the delivery of multipulse feeds is usually combined as a single addition to save time and ease of operation. This may imply a change on the method of delivery of the feed media. ${ }^{248}$

Finally, inoculation and sampling is modified in largescale bioreactors. Cell concentration should be kept constant across scales. For this, inoculation at different scales should use an inoculum of the same in vitro age (to maintain a similar starting biological status of cells) and a similar inoculum percentage (v/v) (to yield a comparable volume increase from inoculation). For its turn, the frequency and size of culture sampling must be defined for each scale. Particularly, the volume losses during sampling should be carefully accounted for in developing the scale-up strategy. ${ }^{248}$

\section{Conclusions}

With the recent advances in medicine, mAbs have assumed an increased importance in the biopharmaceutical industry, especially because of their characteristics of specificity and selectivity. ${ }^{9}$ Indeed, currently, they are the fastest growing biopharmaceutical product, with applications in 
diagnosis and therapy. ${ }^{164}$ Furthermore, the need for high doses of mAbs has led to the rapid development of processes for their large-scale production in mammalian cells, to cope up with the market demands. ${ }^{8}$ Consequently, several production systems have emerged, with specific characteristics, that can be used for different applications, such as adherent or suspension cell culture. However, the systems developed still have major limitations, especially in oxygenation, monitoring, and control of culture conditions, making it currently difficult to reach the full potential of mammalian cells for $\mathrm{mAb}$ production.

To surpass these limitations, a greater knowledge on cells and on the diversity of factors that affect their growth and productivity, as well as the factors interactions has to be obtained. Furthermore, more comparative studies about the production technologies already available are still needed. The combination of an increased know-how about technologies and cell behavior will allow the implementation of more sustained and structured processes of optimization, replacing the current practices based on empirical knowledge and trial-and-error experimentation. This may result in the development of new platforms of cell-culture processes for $\mathrm{mAb}$ production that will reduce costs, simplify the procedures, and ultimately speed-up the delivery of the new products to the market.

\section{Literature Cited}

1. Hudson PJ, Souriau C. Engineered antibodies. Nat Med. 2003;9:129-134.

2. Walsh G. Biopharmaceutical benchmarks 2003. Nat Biotechnol. 2003;21:865-870.

3. Nilsang S, Nandakumar KS, Galaev IY, Rakshit SK, Holmdahl R, Mattiasson B, Kumar A. Monoclonal antibody production using a new supermacroporous cryogel bioreactor. Biotechnol Prog. 2007;23:932-939.

4. Wurm FM. Production of recombinant protein therapeutics in cultivated mammalian cells. Nat Biotechnol. 2004;22:13931398.

5. Werner RG, Noe W, Kopp K, Schlüter M. Appropriate mammalian expression systems for biopharmaceuticals. Drug Res. 1998;48:870-880.

6. Li F, Zhou JX, Yang X, Tressel T, Lee B. Current therapeutic antibody production and process optimization. Bioprocess $J$. 2005;4:1-8.

7. Yoon SK, Hong JK, Choo SH, Song JY, Park HW, Lee GM. Adaptation of Chinese hamster ovary cells to low culture temperature: cell growth and recombinant protein production. J Biotechnol. 2006;122:463-472.

8. Jain E, Kumar A. Upstream processes in antibody production: evaluation of critical parameters. Biotechnol Adv. 2008;26:4671.

9. Chu L, Robinson DK. Industrial choices for protein production by large-scale cell culture. Curr Opin Biotechnol. 2001;12: $180-187$

10. Ozturk SS, Hu W-S. Cell Culture Technology for Pharmaceutical and Cell-Based Therapies. New York: CRC Press; 2006.

11. Butler M. Modes of culture for high cell densities. In: Butler M, editor. Animal Cell Culture and Technology. The Basics. Routledge, UK: Taylor and Francis; Chapter 10, 1996:175194.

12. Zhang S, Thwin C, Wu Z, Cho T, Gallagher S. An improved method for the production and purification of adenoviral vectors. US Patent, WP 2000/032754, 2000.

13. Ho L, Greene CL, Schmidt AW, Huang LH. Cultivation of HEK 293 cell line and production of a member of the superfamily of g-protein coupled receptors for drug discovery applications using a highly efficient novel bioreactor. Cytotechnology. 2004;45:117-123.
14. Aunins JG, Bader B, Caola A, Griffiths J, Katz M, Licari P, Ram K, Ranucci CS, Zhou W. Fluid mechanics, cell distribution, and environment in cell cube bioreactors. Biotechnol Prog. 2003;19:2-8.

15. Carcagno CM, Criscuolo M, Melo C, Vidal JA. Method for the massive culture of cells producing recombinant human erythropoietin. US Patent, WP 2000/027997, 2000.

16. Unger DR, Muzzio FJ, Aunins JG, Singhvi R. Computational and experimental investigation of flow and fluid mixing in the roller bottle bioreactor. Biotechnol Bioeng. 2000;70:117-130.

17. Hong YC, Labuza TP, Harlander SK. Growth kinetics of strawberry cell suspension cultures in shake flask, airlift, stirred-jar, and roller bottle bioreactors. Biotechnol Prog. 1989;5:137-143.

18. Mak NK, Fong WF, Wong-Leung YL. Improved fermentative production of monascus pigments in roller bottle culture. Enzyme Microb Technol. 1990;12:965-968.

19. Berson RE, Friederichs G. A self-feeding roller bottle for continuous cell culture. Biotechnol Prog. 2008;24:154-157.

20. Lee GM, Kim EJ, Kim NS, Yoon SK, Ahn YH, Song JY. Development of a serum-free medium for the production of erythropoietin by suspension culture of recombinant Chinese hamster ovary cells using a statistical design. $J$ Biotechnol. 1999;69:85-93.

21. Rodriguez J, Spearman M, Huzel N, Butler M. Enhanced production of monomeric interferon-beta by $\mathrm{CHO}$ cells through the control of culture conditions. Biotechnol Prog. 2005;21: 22-30.

22. Archer R, Wood L. Production tissue culture by robots. In: Spier RE, Griffiths JB, McDonald C, editors. Animal Cell Technology: Developments, Processes and Products. Oxford: Butterworth-Heinemann; 1992:403-408.

23. Berson RE, Pieczynski WJ, Svihla CK, Hanley TR. Enhanced mixing and mass transfer in a recirculation loop results in high cell densities in a roller bottle reactor. Biotechnol Prog. 2002; 18:72-77.

24. Hunt L, Batard P, Jordan M, Wurm FM. Fluorescent proteins in animal cells for process development: optimization of sodium butyrate treatment as an example. Biotechnol Bioeng. 2002;77:528-537.

25. De Jesus M, Girard P, Bourgeois M, Baumgartner M, Jacko G, Amstutz H, Wurm FM. Tubespin satellites: a fast track approach for process development with animal cells using shaking technology. Biochem Eng J. 2004;17:217-223.

26. Martinelle K, Doverskog M, Jacobsson U, Chapman BE, Kuchel PW, Häggström L. Elevated glutamate dehydrogenase flux in glucose-deprived hybridoma and myeloma cells: evidence from 1H/15N NMR. Biotechnol Bioeng. 1998;60: 508-517.

27. Cowger NL, O'Connor KC, Hammond TG, Lacks DJ, Navar GL. Characterization of bimodal cell death of insect cells in a rotating-wall vessel and shaker flask. Biotechnol Bioeng. 1999;64:14-26.

28. Singh V. Disposable bioreactor for cell culture using waveinduced agitation. Cytotechnology. 1999;30:149-158.

29. Heidemann R, Riese U, Lütkemeyer D, Büntemeyer $H$, Lehmann J. The super-spinner: a low cost animal cell culture bioreactor for the $\mathrm{CO}_{2}$ incubator. Cytotechnology. 1994;14:19.

30. Trebak M, Chong JM, Herlyn D, Speicher DW. Efficient laboratory-scale production of monoclonal antibodies using membrane-based high-density cell culture technology. I Immunol Methods. 1999;230:59-70.

31. Glacken MW, Fleischaker RJ, Sinskey AJ. Large-scale production of mammalian cells and their products: engineering principles and barriers to scale-up. Ann N Y Acad Sci. 1983;413: $355-372$.

32. Gigout A, Buschmann MD, Jolicoeur M. The fate of pluronic F-68 in chondrocytes and $\mathrm{CHO}$ cells. Biotechnol Bioeng. 2008;100:975-987.

33. Dong H, Tang YJ, Ohashi R, Hamel JF. A perfusion culture system using a stirred ceramic membrane reactor for hyperproduction of IgG2a monoclonal antibody by hybridoma cells. Biotechnol Prog. 2005;21:140-147. 
34. Guez JS, Cassar JP, Wartelle F, Dhulster P, Suhr H. Real time in situ microscopy for animal cell-concentration monitoring during high density culture in bioreactor. J Biotechnol. 2004; 111:335-343.

35. Mel M, Abdul Rahman A, Mohamed Salleh M, Has-Yun Hashim Y. Monoclonal antibody production: viability improvement of RC1 hybridoma cell in different types of bioreactor. World J Microbiol Biotechnol. 2008;24:1923-1927.

36. Stacey G, Davis J. Medicines from Animal Cell Culture. Chichester: Wiley; 2007.

37. Finter NB. Animal cell culture: the problems and rewards. In: Spier RE, Griffiths JB, Meignier B, editors. Production of Biologicals from Animal Cells in Culture. Oxford: ButterworthHeinemann; 1991:3-12.

38. Michaels JD, Mallik AK, Papoutsakis ET. Sparging and agitation-induced injury of cultured animals cells: do cell-to-bubble interactions in the bulk liquid injure cells? Biotechnol Bioeng. 1996;51:399-409.

39. Shi Y, Ryu DD, Park SH. Performance of mammalian cell culture bioreactor with a new impeller design. Biotechnol Bioeng. 1992;40:260-270.

40. Freshney RI. Culture of Animal Cells: A Manual of Basic Technique, 5th ed. New Jersey: Wiley; 2005.

41. Hülscher M, Scheibler U, Onken U. Selective recycle of viable animal cells by coupling of airlift reactor and cell settler. Biotechnol Bioeng. 1992;39:442-446.

42. Boraston SJFRC, Marshall CM, Gardiner SAM. The effect of high gas sparge rates in airlift fermenter culture on hybridoma cell growth and antibody production in low protein medium. In: Spier RE, Griffiths JB, MacDonald C, editors. Animal Cell Technology: Developments, Process and Products. Oxford: Butterworth-Heinemann; 1992:218-220.

43. Merchuk JC. Why use air-lift bioreactors? Trends Biotechnol. 1990;8:66-71.

44. Birch JR, Arathoon R. Suspension culture of mammalian cells. Bioprocess Technol. 1990;10:251-270.

45. Varley J, Birch J. Reactor design for large scale suspension animal cell culture. Cytotechnology. 1999;29:177-205.

46. Papoutsakis ET. Fluid-mechanical damage of animal cells in bioreactors. Trends Biotechnol. 1991;9:427-437.

47. Molina Grima E, Chisti Y, Moo-Young M. Characterization of shear rates in airlift bioreactors for animal cell culture. $J$ Biotechnol. 1997;54:195-210.

48. Genzel Y, Olmer RM, Schäfer B, Reichl U. Wave microcarrier cultivation of MDCK cells for influenza virus production in serum containing and serum-free media. Vaccine. 2006;24:60746087.

49. Pierce LN, Shabram PW. Scalability of a disposable bioreactor from $25 \mathrm{~L}-500 \mathrm{~L}$ run in perfusion mode with CHO-based cell line: a tech review. Bioprocess J. 2004;3:51-56.

50. Fries S, Glazomitsky K, Woods A, Forrest G, Hsu A, Olewinski R, Robinson D, Chartrain M. Evaluation of disposable bioreactors-rapid production of recombinant proteins by several animal cell lines. Bioprocess Int. 2005;3:36-44.

51. Namdev PK, Lio P. Assessing a disposable bioreactor for attachment-dependant cell cultures. Biopharm Int. 2000;13:44-50.

52. Palazón J, Mallol A, Eibl R, Lettenbauer C, Cusidó RM, Piñol MT. Growth and ginsenoside production in hairy root cultures of panax ginseng using a novel bioreactor. Planta Med. 2003;69:344-349.

53. Weber W, Weber E, Geisse S, Memmert K. Optimisation of protein expression and establishment of the wave bioreactor for Baculo virus/insect cell culture. Cytotechnology. 2002;38: $77-85$.

54. Hundt B, Schänzler A, Reichl U. Serum free cultivation of primary chicken embryo fibroblasts in microcarrier systems for vaccine production. In: Gòdia F, Fussenegger M, editors. Animal Cell Technology Meets Genomics. Dordrecht: Springer, 2005: 771-774.

55. Kadarusman J, Bhatia R, McLaughlin J, Lin WR. Growing cholesterol-dependent NSO myeloma cell line in the wave bioreactor system: overcoming cholesterol-polymer interaction by using pretreated polymer or inert fluorinated ethylene propylene. Biotechnol Prog. 2005;21:1341-1346.
56. Genzel Y, Fischer M, Olmer R, Schäfer B, Best C, König S, Hundt B, Reichl U. Serum-free influenza vaccine production with MDCK cells in wave-bioreactor and 5L-stirred tank bioreactor. In: Smith R, editor. Cell Technology for Cell Products-Proceedings of the 19th ESACT Meeting. Netherlands: Springer; 2007:563-565.

57. Mikola M, Seto J, Amanullah A. Evaluation of a novel wave bioreactor ${ }^{\circledR}$ cellbag for aerobic yeast cultivation. Bioprocess Biosyst Eng. 2007;30:231-241.

58. Tang Y-J, Ohashi R, Hamel J-FP. Perfusion culture of hybridoma cells for hyperproduction of IgG2a monoclonal antibody in a wave bioreactor-perfusion culture system. Biotechnol Prog. 2007;23:255-264.

59. Pörtner R, Rössing S, Koop M, Lüdemann I. Kinetic studies on hybridoma cells immobilized in fixed bed reactors. Biotechnol Bioeng. 1997;55:535-541.

60. Zhu H, Yang S-T. Long-term continuous production of monoclonal antibody by hybridoma cells immobilized in a fibrousbed bioreactor. Cytotechnology. 2004;44:1-14.

61. Kwaks THJ, Barnett P, Hemrika W, Siersma T, Sewalt RGAB, Satijn DPE, Brons JF, van Blokland R, Kwakman P, Kruckeberg AL, Kelder A, Otte AP. Identification of anti-repressor elements that confer high and stable protein production in mammalian cells. Nat Biotechnol. 2003;21:553-558.

62. Fernandez LA, Winkler M, Grosschedl R. Matrix attachment region-dependent function of the immunoglobulin \{micro\} enhancer involves histone acetylation at a distance without changes in enhancer occupancy. Mol Cell Biol. 2001;21:196-208.

63. Griffiths B. Perfusion systems for cell cultivation. In: Lubiniecki AS, editor. Large-Scale Mammalian Cell Culture Technology. Orlando: CRC Press; 1990:217-250.

64. Ziao C, Huang Z, Li W, Hu X, Qu W, Gao L, Liu G. High density and scale-up cultivation of recombinant cho cell line and hybridomas with porous microcarrier cytopore. In: Merten $\mathrm{O}-\mathrm{W}$, Perrin P, Griffiths B, editors. New Developments and New Applications in Animal Cell Technology. Netherland: Lavoisier; 2002:389-393.

65. Kong D, Chen M, Gentz R, Zhang J. Cell growth and protein formation on various microcarriers. Cytotechnology. 1999;29: 151-158.

66. Van Wezel AL. Growth of cell-strains and primary cells on micro-carriers in homogeneous culture. Nature. 1967;216:64-65.

67. Lee GM, Varma A, Palsson BO. Production of monoclonal antibody using free-suspended and immobilized hybridoma cells: effect of serum. Biotechnol Bioeng. 1991;38:821-830.

68. Cadic C, Dupuy B, Pianet I, Merle M, Margerin C, Bezian JH. In vitro culture of hybridoma cells in agarose beads producing antibody secretion for two weeks. Biotechnol Bioeng. 1992;39: $108-112$.

69. Li X, Liu T, Song K, Yao L, Ge D, Bao C, Ma X, Cui Z. Culture of neural stem cells in calcium alginate beads. Biotechnol Prog. 2006;22:1683-1689.

70. Yamaguchi M, Shirai Y, Inouye Y, Shoji M, Kamei M, Hashizume S, Shirahata $\mathrm{S}$. Changes in monoclonal antibody productivity of recombinant BHK cells immobilized in collagen gel particles. Cytotechnology. 1997;23:5-12.

71. Klement G, Scheirer W, Katinger HW. Construction of a large scale membrane reactor system with different compartments for cells, medium and product. Dev Biol Stand. 1987;66:221226.

72. Scheirer W. High-density growth of animal cells within cell retention fermenters equipped with membranes. In: Spier RE, Griffiths JB, editors. Animal Cell Biotechnology, Vol. 3. London: Academic Press; 1988:263-281.

73. Rupp RG. Use of cellular micro-encapsulation in large-scale production of monoclonal antibodies. In: Feder J, Tolbert WR, editors. Large-Scale Mammalian Cell Culture. Orlando: Academic Press; 1985:19-38.

74. Yang S-T, Luo J, Chen C. A fibrous-bed bioreactor for continuous production of monoclonal antibody by hybridoma. In: Scheper T, editor. Biomanufacturing. Berlin: Springle, 2004: 61-96.

75. Valdés R, Ibarra N, González M, Alvarez T, García J, Llambias R, Pérez C, Quintero O, Fischer R. CB.Hep-1 hybridoma 
growth and antibody production using protein-free medium in a hollow fiber bioreactor. Cytotechnology. 2001;35:145-154.

76. Chiou TW, Murakami S, Wang DIC, Wu WT. A fiber-bed bioreactor for anchorage-dependent animal cell cultures. I. Bioreactor design and operations. Biotechnol Bioeng. 1991;37: 755-761.

77. Wang G, Zhang W, Friedman D, Eppstein L, Kadouri A. Continuous production of monoclonal antibodies in celligen packed bed reactor using fiber-cel carrier. In: Spier RE, Griffiths JB, MacDonald C, editors. Animal Cell Technology: Developments, Process and Products. Oxford: ButterworthHeinemann; 1992:460-464.

78. Emery AN, Lavery M, Williams B, Handa A. Large-scale hybridoma culture. In: Webb $\mathrm{C}$, Mavituna F, editors. Plant and Animal Cells: Process Possibilities. Chichester: Ellis Horwood; 1987:137-146

79. de la Broise D, Noiseux M, Massie B, Lemieux R. Hybridoma perfusion systems: a comparison study. Biotechnol Bioeng. 1992;40:25-32.

80. Velden-de Groot CAM. Microcarrier technology, present status and perspective. Cytotechnology. 1995;18:51-56.

81. Butler M. Growth limitations in microcarrier cultures. Adv Biochem Eng. 1987;34:57-84.

82. Hirtenstein M, Clark J, Lindgren G, Vretblad P. Microcarriers for animal cell culture: a brief review of theory and practice. Dev Biol Stand. 1980;46:109-116.

83. Blüml G. Microcarrier cell culture technology. In: Pörtner R, editor. Animal Cell Biotechnology: Methods and Protocols, 2nd ed. Totowa, NJ: Humana Press; 2007:149-178.

84. Malda J, Frondoza CG. Microcarriers in the engineering of cartilage and bone. Trends Biotechnol. 2006;24:299-304.

85. Almgren J, Nilsson C, Peterson AC, Nilsson K. Cultisphermacroporous gelatine microcarrier-new applications. In: Spier RE, Griffiths JB, Meignier B, editors. Production of Biologicals from Animal Cells in Culture. Oxford: Butterworth-Heinemann; 1991:434-438.

86. Voigt A, Zintl F. Hybridoma cell growth and anti-neuroblastoma monoclonal antibody production in spinner flasks using a protein-free medium with microcarriers. J Biotechnol. 1999;68: 213-226.

87. Wang Y, Ouyang F. Bead-to-bead transfer of vero cells in microcarrier culture. Bioprocess Biosyst Eng. 1999;21:211213.

88. Kong D, Gentz R, Zhang J. Long-term stable production of monocyte-colony inhibition factor (M-CIF) from CHO microcarrier perfusion cultures. Cytotechnology. 1998;26:131-138.

89. Hu X, Xiao C, Huang Z, Guo Z, Zhang Z, Li Z. Pilot production of u-PA with porous microcarrier cell culture. Cytotechnology. 2000;33:13-19.

90. Glacken MW, Fleischaker RJ, Sinskey AJ. Reduction of waste product excretion via nutrient control: possible strategies for maximizing product and cell yields on serum in cultures of mammalian cells. Biotechnol Bioeng. 1986;28:1376-1389.

91. van Wezel AL, van der Velden-de Groot CA, de Haan HH, van den Heuvel N, Schasfoort R. Large scale animal cell cultivation for production of cellular biologicals. Dev Biol Stand. 1985;60:229-236.

92. Fenge C, Klein C, Heuer C, Siegel U, Fraune E. Agitation, aeration and perfusion modules for cell culture bioreactors. Cytotechnology. 1993;11:233-244.

93. Butler M, Imamura T, Thomas J, Thilly WG. High yields from microcarrier cultures by medium perfusion. J Cell Sci. 1983; 61:351-363.

94. Croughan MS, Wang DIC. Growth and death in overagitated microcarrier cell cultures. Biotechnol Bioeng. 1989;33:731744.

95. Martens DE, Nollen EAA, Hardeveld M, Velden-de Groot CAM, Gooijer CD, Beuvery EC, Tramper J. Death rate in a small air-lift loop reactor of vero cells grown on solid microcarriers and in macroporous microcarriers. Cytotechnology. 1996;21:45-59.

96. Hambach P, Biselli M, Runstadler PW, Wandrey C. Development of a reactor-integrated aeration system for cultivation of animal cells in fluidized beds. In: Spier RE, Griffiths JB, Mac-
Donald C, editors. Animal Cell Technology: Developments, Process and Products. Oxford: Butterworth-Heinemann; 1992: 381-385.

97. Born C, Biselli M, Wandrey C. Production of monoclonal antibodies in a pilot scale fluidized bed bioreactor. In: Beuvery EC, Griffiths JB, Zeijlemaker WP, editors. Animal Cell Technology: Developments towards the 21st Century. Dordrecht: Kluwer Academic Publishers; 1995:683-686.

98. Biselli M, Born C, Scr Oder B, Wandrey C. Gasification-tube module and reactor for cell cultivation. US Patent 5,601,757, Forschungszentrum Julich GmbH, 1997.

99. Nam JH, Ermonval M, Sharfstein ST. Cell attachment to microcarriers affects growth, metabolic activity, and culture productivity in bioreactor culture. Biotechnol Prog. 2007;23: 652-660.

100. Gramer M, Maas J, Lieberman M. Use of hollow fiber systems for rapid and direct scale up of antibody production from hybridoma cell lines cultured in CL-1000 flasks using BD cell MAb medium. Cytotechnology. 2003;42:155-162.

101. Jackson LR, Trudel LJ, Fox JG, Lipman NS. Evaluation of hollow fiber bioreactors as an alternative to murine ascites production for small scale monoclonal antibody production. J Immunol Methods. 1996;189:217-231.

102. Pörtner R. Animal Cell Biotechnology: Methods and Protocols, 2nd ed. Totowa, NJ: Humana Press; 2007.

103. Gramer MJ, Poeschl DM. Screening tool for hollow-fiber bioreactor process development. Biotechnol Prog. 1998;14:203209.

104. Dowd JE, Weber I, Rodriguez B, Piret JM, Kwok KE. Predictive control of hollow-fiber bioreactors for the production of monoclonal antibodies. Biotechnol Bioeng. 1999;63: 484-492.

105. Meuwly F, Ruffieux PA, Kadouri A, von Stockar U. Packedbed bioreactors for mammalian cell culture: bioprocess and biomedical applications. Biotechnol Adv. 2007;25:45-56.

106. Looby D, Griffiths JB. Fixed bed porous glass sphere (porosphere) bioreactors for animal cells. Cytotechnology. 1988;1: 339-346.

107. Wang G, Zhang W, Jacklin C, Freedman D, Eppstein L, Kadouri A. Modified celligen-packed bed bioreactors for hybridoma cell cultures. Cytotechnology. 1992;9:41-49.

108. Earle WR, Bryant JC, Schilling EL. Certain factors limiting the size of the tissue culture and the development of massive cultures. Ann N Y Acad Sci. 1954;58:1000-1011.

109. Grampp GE, Applegate MA, Stephanopoulos G. Cyclic operation of ceramic-matrix animal cell bioreactors for controlled secretion of an endocrine hormone. A comparison of singlepass and recycle modes of operation. Biotechnol Prog. 1996; $12: 837-846$.

110. Kim BS, Putnam AJ, Kulik TJ, Mooney DJ. Optimizing seeding and culture methods to engineer smooth muscle tissue on biodegradable polymer matrices. Biotechnol Bioeng. 1998;57: 46-54.

111. Gümüsderelioglu M, Aslankaraoglu E, Gürhan SI. Rabies virus production in non-woven polyester fabric(NWPF) packed-bed reactors. Biotechnol Appl Biochem. 2001;33:167-172.

112. Hanak JAJ, Davis JM. Hollow fiber bioreactors: the endotronics acusyst-Jr and maximiser 500. In: Doyle A, Griffiths JB, Newell DG, editors. Cell and Tissue Culture: Laboratory Procedures. Chichester: Wiley; 1995:3.

113. Nyberg SL, Shatford RA, Peshwa MV, White JG, Cerra FB, $\mathrm{Hu}$ WS. Evaluation of a hepatocyte-entrapment hollow fiber bioreactor: a potential bioartificial liver. Biotechnol Bioeng. 1993;41:194-203.

114. Junker BH, Chiou T, Wang DIC, Buckland BC. Cultivation of virus antigen in fibroblast cells using a glass fiber bed reactor. Biotechnol Bioeng. 1993;42:635-642.

115. Starling EH. On the absorption of fluids from the connective tissue spaces. $J$ Physiol. 1896;19:312-326.

116. Looby D, Griffiths B. Immobilization of animal cells in porous carrier culture. Trends Biotechnol. 1990;8:204-209.

117. Kurosawa H, Markl H, Niebuhr-Redder C, Matsumura M. Dialysis bioreactor with radial-flow fixed bed for animal cell culture. J Ferment Bioeng. 1991;72:41-45. 
118. Bohmann A, Pörtner R, Märkl H. Performance of a membrane-dialysis bioreactor with a radial-flow fixed bed for the cultivation of a hybridoma cell line. Appl Microbiol Biotechnol. 1995;43:772-780.

119. Backer MP, Metzger LS, Slaber PL, Nevitt KL, Boder GB. Large-scale production of monoclonal antibodies in suspension culture. Biotechnol Bioeng. 1988;32:993-1000.

120. Noe W, Bux R, Werner RG, Berthold W. Aspects of continuous culture versus batch mode for animal cells in industrial processes. In: Spier RE, Griffiths JB, MacDonald C, editors. Animal Cell Technology: Developments, Processes and Products. Oxford: Butterworth-Heinemann; 1992:354-360.

121. Xie L, Wang DI. Fed-batch cultivation of animal cells using different medium design concepts and feeding strategies. Biotechnol Bioeng. 1994;43:1175-1189.

122. Merten OW, Palfi GE, Element G, Steindl F. Specific kinetic patterns of production of monoclonal antibodies in batch cultures and consequences on fermentation processes. In: Spier RE, Griffiths JB, editors. Modern Approaches to Animal Cell Technology. Oxford: Butterworth; 1987:381-396.

123. Phillips PJ, Marquis CP, Barford JP, Harbour C. An analysis of some batch and continuous kinetic data of specific monoclonal antibodt production from hybridomas. Cytotechnology. 1991;6:189-195.

124. Sandadi S, Ensari S, Kearns B. Heuristic optimization of antibody production by Chinese hamster ovary cells. Biotechnol Prog. 2005;21:1537-1542.

125. Dorka P, Fischer C, Budman H, Scharer J. Metabolic fluxbased modeling of $\mathrm{mAb}$ production during batch and fed-batch operations. Bioproces Biosyst Eng. 2009;32:183-196.

126. Tovey MG. The cultivation of animal cells in continuous-flow culture. In: Spier RE, Griffiths JB, editors. Animal Cell Biotechnology. London: Academic Press; 1985:195-210.

127. Bonarius HPJ. Method for producing heterologous proteins in eukaryotic cells on an industrial scale using nucleotide-manipulating agents. US Patent, WP 1999/032605, 1999.

128. Stiens LR, Büntemeyer H, Lütkemeyer D, Lehmann J, Bergmann A, Weglöhner W. Development of serum-free bioreactor production of recombinant human thyroid stimulating hormone receptor. Biotechnol Prog. 2000;16:703-709.

129. Iding K, Lutkemeyer D, Fraune E, Gerlach K, Lehmann J. Influence of alterations in culture condition and changes in perfusion parameters on the retention performance of a 20 $\mu \mathrm{m}$ spinfilter during a perfusion cultivation of a recombinant CHO cell line in pilot scale. Cytotechnology. 2000;34:141150.

130. Yang J-D, Angelillo Y, Chaudhry M, Goldenberg C, Goldenberg DM. Achievement of high cell density and high antibody productivity by a controlled-fed perfusion bioreactor process. Biotechnol Bioeng. 2000;69:74-82.

131. Furey J. Continuous cell culture using the ATF system. Genet Eng News. 2000;20:52-53.

132. Voisard D, Meuwly F, Ruffieux PA, Baer G, Kadouri A. Potential of cell retention techniques for large-scale high-density perfusion culture of suspended mammalian cells. Biotechnol Bioeng. 2003;82:751-765.

133. Ryll T, Dutina G, Reyes A, Gunson J, Krummen L, Etcheverry T. Performance of small-scale $\mathrm{CHO}$ perfusion cultures using an acoustic cell filtration device for cell retention: characterization of separation efficiency and impact of perfusion on product quality. Biotechnol Bioeng. 2000;69:440-449.

134. Woolley JF, Al-Rubeai M. The application of SELDI-TOF mass spectrometry to mammalian cell culture. Biotechnol Adv. 2009;27:177-184.

135. Trummer E, Fauland K, Seidinger S, Schriebl K, Lattenmayer C, Kunert R, Vorauer-Uhl K, Weik R, Borth N, Katinger H, Müller D. Process parameter shifting. I. Effect of DOT, pH, and temperature on the performance of Epo-Fc expressing $\mathrm{CHO}$ cells cultivated in controlled batch bioreactors. Biotechnol Bioeng. 2006;94:1033-1044.

136. Kaufmann H, Mazur X, Fussenegger M, Bailey JE. Influence of low temperature on productivity, proteome and protein phosphorylation of CHO cells. Biotechnol Bioeng. 1999;63: 573-582.
137. Roessler B, Luebben H, Kretzmer G. Temperature: a simple parameter for process optimization in fed-batch cultures of recombinant Chinese hamster ovary cells. Enzyme Microb Technol. 1996;18:423-427.

138. Bollati-Fogolín M, Forno G, Nimtz M, Conradt HS, Etcheverrigaray $\mathrm{M}$, Kratje R. Temperature reduction in cultures of hGM-CSF-expressing CHO cells: effect on productivity and product quality. Biotechnol Prog. 2005;21:17-21.

139. Yoon SK, Choi SL, Song JY, Lee GM. Effect of culture $\mathrm{pH}$ on erythropoietin production by Chinese hamster ovary cells grown in suspension at 32.5 and $37.0^{\circ} \mathrm{C}$. Biotechnol Bioeng. 2005;89:345-356.

140. Mohan CM, Kim Y-G, Koo J, Lee GM. Assessment of cell engineering strategies for improved therapeutic protein production in CHO cells. Biotechnol J. 2008;3:624-630.

141. Fox SR, Patel UA, Yap MGS, Wang DIC. Maximizing interferon-gamma production by Chinese hamster ovary cells through temperature shift optimization: experimental and modeling. Biotechnol Bioeng. 2004;85:177-184.

142. Oguchi S, Saito H, Tsukahara M, Tsumura H. pH condition in temperature shift cultivation enhances cell longevity and specific hMab productivity in $\mathrm{CHO}$ culture. Cytotechnology. 2006;52:199-207.

143. Hanson MA, Ge X, Kostov Y, Brorson KA, Moreira AR, Rao G. Comparisons of optical $\mathrm{pH}$ and dissolved oxygen sensors with traditional electrochemical probes during mammalian cell culture. Biotechnol Bioeng. 2007;97:833-841.

144. Borys MC, Linzer DIH, Papoutsakis ET. Culture pH affects expression rates and glycosylation of recombinant mouse placental lactogen proteins by Chinese hamster ovary $(\mathrm{CHO})$ cells. Nat Biotechnol. 1993;11:720-724.

145. Jardon $\mathrm{M}$, Garnier A. $\mathrm{pH}, \mathrm{pCO}_{2}$, and temperature effect on $\mathrm{R}$ adenovirus production. Biotechnol Prog. 2003;19:202-208.

146. Griffiths B. Scaling-up of animal cell cultures. In: Masters JRW, editor. Animal Cell Culture: A Practical Approach. Oxford: Oxford University Press; 2000:19-66.

147. Sauer PW, Burky JE, Wesson MC, Sternard HD, Qu L. A high-yielding, generic fed-batch cell culture process for production of recombinant antibodies. Biotechnol Bioeng. 2000; 67:585-597.

148. Good NE, Winget GD, Winter W, Connolly TN, Izawa S, Singh RMM. Hydrogen ion buffers for biological research. Biochemistry. 1966;5:467-477.

149. Leibovitz A. The growth and maintenance of tissue-cell cultures in free gas exchange with the atmosphere. Am J Epidemiol. 1963;78:173-180.

150. Bibila TA, Ranucci CS, Glazomitsky K, Buckland C, Aunins JG. Monoclonal antibody process development using medium concentrates. Biotechnol Prog. 1994;10:87-96.

151. Miller WM, Blanch HW, Wilke CR. A kinetic analysis of hybridoma growth and metabolism in batch and continuous suspension culture: effect of nutrient concentration, dilution rate, and pH. Biotechnol Bioeng. 1988;32:947-965.

152. deZengotita VM, Schmelzer AE, Miller WM. Characterization of hybridoma cell responses to elevated $\mathrm{pCO}_{2}$ and osmolality: intracellular $\mathrm{pH}$, cell size, apoptosis, and metabolism. Biotechnol Bioeng. 2002;77:369-380.

153. Kim MS, Kim NS, Sung YH, Lee GM. Biphasic culture strategy based on hyperosmotic pressure for improved humanized antibody production in Chinese hamster ovary cell culture. In Vitro Cell Dev Biol Anim. 2002;38:314-319.

154. Jorjani P, Ozturk SS. Effects of cell density and temperature on oxygen consumption rate for different mammalian cell lines. Biotechnol Bioeng. 1999;64:349-356.

155. Kunkel JP, Jan DC, Jamieson JC, Butler M. Dissolved oxygen concentration in serum-free continuous culture affects $\mathrm{N}$-linked glycosylation of a monoclonal antibody. J Biotechnol. 1998; 62:55-71.

156. McLimans WF. The gaseous environment of the mammalian cell in culture. In: Rothblat GH, Quitofalo VJ, editors. Growth, Nutrition, and Metabolism of Cells in Culture. London: Academic Press; 1972:137-169.

157. Pattison RN, Swamy J, Mendenhall B, Hwang C, Frohlich BT. Measurement and control of dissolved carbon dioxide in 
mammalian cell culture processes using an in situ fiber optic chemical sensor. Biotechnol Prog. 2000;16:769-774.

158. Takuma S, Hirashima C, Piret JM. Dependence on glucose limitation of the $\mathrm{pCO}_{2}$ influences on $\mathrm{CHO}$ cell growth, metabolism and IgG production. Biotechnol Bioeng. 2007;97:14791488 .

159. Schmelzer AE, Miller WM. Hyperosmotic stress and elevated $\mathrm{pCO}_{2}$ alter monoclonal antibody charge distribution and monosaccharide content. Biotechnol Prog. 2002;18:346-353.

160. Gray DR, Chen S, Howarth W, Inlow D, Maiorella BL. $\mathrm{CO}_{2}$ in large-scale and high-density $\mathrm{CHO}$ cell perfusion culture. Cytotechnology. 1996;22:65-78.

161. Mostafa SS, Gu X. Strategies for improved $\mathrm{dCO}_{2}$ removal in large-scale fed-batch cultures. Biotechnol Prog. 2003;19:4551.

162. Kimura R, Miller WM. Effects of elevated $\mathrm{pCO}_{2}$ and/or osmolality on the growth and recombinant tPA production of $\mathrm{CHO}$ cells. Biotechnol Bioeng. 1996;52:152-160.

163. deZengotita V, Kimura R, Miller W. Effects of $\mathrm{CO}_{2}$ and osmolality on hybridoma cells: growth, metabolism and monoclonal antibody production. Cytotechnology. 1998;28:213-227.

164. Kontoravdi C, Asprey SP, Pistikopoulos EN, Mantalaris A. Development of a dynamic model of monoclonal antibody production and glycosylation for product quality monitoring. Comput Chem Eng. 2007;31:392-400.

165. Lao M-S, Toth D. Effects of ammonium and lactate on growth and metabolism of a recombinant Chinese hamster ovary cell culture. Biotechnol Prog. 1997;13:688-691.

166. Nyberg GB, Balcarcel RR, Follstad BD, Stephanopoulos G, Wang DI. Metabolic effects on recombinant interferon- $\gamma$ glycosylation in continuous culture of Chinese hamster ovary cells. Biotechnol Bioeng. 1999;62:336-347.

167. Europa AF, Gambhir A, Fu PC, Hu WS. Multiple steady states with distinct cellular metabolism in continuous culture of mammalian cells. Biotechnol Bioeng. 2000;67:25-34.

168. Zhou W, Rehm J, Europa A, Hu W-S. Alteration of mammalian cell metabolism by dynamic nutrient feeding. Cytotechnology. 1997;24:99-108.

169. Altamirano C, Cairo JJ, Godia F. Decoupling cell growth and product formation in Chinese hamster ovary cells through metabolic control. Biotechnol Bioeng. 2001;76:351-360.

170. Murakami H. Serum-free media used for cultivation of hybridomas. In: Mizrahi A, editor. Advances in Biotechnological Processes. New York: Alan R. Liss; 1989:107-141.

171. Butler M. Optimisation of the cellular metabolism of glycosylation for recombinant proteins produced by mammalian cell systems. Cytotechnology. 2006;50:57-76.

172. Storring PL. Assaying glycoprotein hormones: the influence of glycosylation on immunoreactivity. Cell. 1992;10:427-432.

173. Restelli V, Butler M. The effect of cell culture parameters on protein glycosylation. In: Al-Rubeai M, editor. Glycosylation. Cell Engineering. Dordrecht: Kluwer Publishers; 2002: 61-92.

174. Quan C, Alcala E, Petkovska I, Matthews D, Canova-Davis E, Taticek R, Ma S. A study in glycation of a therapeutic recombinant humanized monoclonal antibody: where it is, how it got there, and how it affects charge-based behavior. Anal Biochem. 2008;373:179-191.

175. Jefferis R. Glycosylation of recombinant antibody therapeutics. Biotechnol Prog. 2005;21:11-16.

176. Curling EM, Hayter PM, Baines AJ, Bull AT, Gull K, Strange PG, Jenkins N. Recombinant human interferon- $\gamma$. Differences in glycosylation and proteolytic processing lead to heterogeneity in batch culture. Biochem J. 1990;272:333-337.

177. Clark KJ, Griffiths J, Bailey KM, Harcum SW. Gene-expression profiles for five key glycosylation genes for galactose-fed $\mathrm{CHO}$ cells expressing recombinant IL-4/13 cytokine trap. Biotechnol Bioeng. 2005;90:568-577.

178. Goochee CF, Monica T. Environmental effects on protein glycosylation. Nat Biotechnol. 1990;8:421-427.

179. Andersen DC, Bridges T, Gawlitzek M, Hoy C. Multiple cell culture factors can affect the glycosylation of Asn-184 in CHO-produced tissue-type plasminogen activator. Biotechnol Bioeng. 2000;70:25-31.
180. Hartnett T. Instrumentation and control of bioprocesses. In: Lydersen BK, D'Elia NA, Nelson KL, editors. Bioprocess Engineering: Systems, Equipment, and Facilities. New York: Wiley; 1994:413-468.

181. Seborg DE, Edgar TF, MelliChamp DA. Process Dynamics and Control. New York: Wiley; 1989.

182. Schmid G, Blanch HW, Wilke CR. Hybridoma growth, metabolism, and product formation in HEPES-buffered medium. II. Effect of pH. Biotechnol Lett. 1990;12:633-638.

183. Naciri M, Kuystermans D, Al-Rubeai M. Monitoring $\mathrm{pH}$ and dissolved oxygen in mammalian cell culture using optical sensors. Cytotechnology. 2008;57:245-250.

184. Sotomayor MDT, De Paoli MA, deOliveira WA. Fiber-optic $\mathrm{pH}$ sensor based on poly(o-methoxyaniline). Anal Chim Acta. 1997;353:275-280.

185. Weidgans BM, Krause C, Klimant I, Wolfbeis OS. Fluorescent $\mathrm{pH}$ sensors with negligible sensitivity to ionic strength. Analyst. 2004;129:645-650.

186. Ozturk SS, Palsson BO. Effects of dissolved oxygen on hybridoma cell growth, metabolism, and antibody production kinetics in continuous culture. Biotechnol Prog. 1990;6:437446.

187. Hesselink PGM. Operational Modes of Bioreactors, Chapter 2. Oxford: Butterworth-Heinemann; 1992.

188. White SF, Turner APF, Biltewski U, Bradley J, Schmid RD. On-line monitoring of glucose, glutamate and glutamine during mammalian cell cultivations. Biosens Bioelectron. 1995;10: $543-551$.

189. Chuang H, Arnold MA. Radioluminescent light source for optical oxygen sensors. Anal Chem. 1997;69:1899-1903.

190. Reece J, Miller M, Arnold M, Waterhouse C, Delaplaine T, Cohn L, Cannon T. Continuous oxygen monitoring of mammalian cell growth on space shuttle mission STS-93 with a novel radioluminescent oxygen sensor. Appl Biochem Biotechnol. 2003;104:1-11.

191. Ge X, Tolosa L, Simpson J, Rao G. Genetically engineered binding proteins as biosensors for fermentation and cell culture. Biotechnol Bioeng. 2003;84:723-731.

192. Griffiths JB. Overview of cell culture systems and their scaleup. In: Spier RE, Griffiths JB, editors. Animal Cell Biotechnology. London: Academic Press; 1988:179-220.

193. Frahm B, Blank H-C, Cornand P, Oelssner W, Guth U, Lane $\mathrm{P}$, Munack A, Johannsen K, Pörtner R. Determination of dissolved $\mathrm{CO}_{2}$ concentration and $\mathrm{CO}_{2}$ production rate of mammalian cell suspension culture based on off-gas measurement. J Biotechnol. 2002;99:133-148.

194. Mills A, Eaton K. Optical sensors for carbon dioxide: an overview of sensing strategies past and present. Quim Anal. 2000;19:75-86.

195. Wolfbeis OS. Fiber-optic chemical sensors and biosensors. Anal Chem. 2000;72:81-90.

196. Schoenherr I, Stapp T, Ryll T. A comparison of different methods to determine the end of exponential growth in $\mathrm{CHO}$ cell cultures for optimization of scale-up. Biotechnol Prog. 2000;16:815-821.

197. Konstantinov K, Chuppa S, Sajan E, Tsai Y, Yoon S, Golini F. Real-time biomass-concentration monitoring in animal-cell cultures. Cell. 1994;12:324-333.

198. Harding CL, Lloyd DR, McFarlane CM, Al-Rubeai M. Using the microcyte flow cytometer to monitor cell number, viability, and apoptosis in mammalian cell culture. Biotechnol Prog. 2000;16:800-802.

199. Shah D, Clee P, Boisen S, Al-Rubeai M. Nucleo counteran efficient technique for the determination of cell number and viability in animal cell culture processes. In: Smith R, editor. Cell Technology for Cell Products. Dordrecht: Springer; 2007: 535-538.

200. Mukwena NT, Veraitch F, Santhalingham S, Al-Rubeai M, Goix P. At-line monitoring of cell cultures: rapid cytometric evaluation of cellular physiology. Guava Technologies. Application note, 2003.

201. Sitton G, Srienc F. Mammalian cell culture scale-up and fedbatch control using automated flow cytometry. J Biotechnol. 2008;135:174-180. 
202. Locher G, Sonnleitner B, Fiechter A. On-line measurement in biotechnology: exploitation, objectives and benefits. $J$ Biotechnol. 1992;25:55-73.

203. Konstantinov KB, Pambayun R, Matanguihan R, Yoshida T, Perusich $\mathrm{CM}, \mathrm{Hu}$ WS. On-line monitoring of hybridoma cell growth using a laser turbidity sensor. Biotechnol Bioeng. 1992; 40:1337-1342.

204. Cannizzaro C, Gugerli R, Marison I, von Stockar U. On-line biomass monitoring of $\mathrm{CHO}$ perfusion culture with scanning dielectric spectroscopy. Biotechnol Bioeng. 2003;84:597-610.

205. Arnold SA, Crowley J, Woods N, Harvey LM, McNeil B. In-situ near infrared spectroscopy to monitor key analytes in mammalian cell cultivation. Biotechnol Bioeng. 2003;84:1319.

206. Zhao R, Natarajan A, Srienc F. A flow injection flow cytometry system for on-line monitoring of bioreactors. Biotechnol Bioeng. 1999;62:609-617.

207. Kacmar J, Srienc F. Dynamics of single cell property distributions in Chinese hamster ovary cell cultures monitored and controlled with automated flow cytometry. J Biotechnol. 2005; 120:410-420.

208. Joeris K, Frerichs JG, Konstantinov K, Scheper T. In-situ microscopy: online process monitoring of mammalian cell cultures. Cytotechnology. 2002;38:129-134.

209. Simpson NH, Singh RP, Perani A, Goldenzon C, Al-Rubeai M. In hybridoma cultures, deprivation of any single amino acid leads to apoptotic death, which is suppressed by the expression of the bcl-2 gene. Biotechnol Bioeng. 1998;59:9098.

210. Swartz ME. UPLC: an introduction and review. J Liq Chromatogr Relat Technol. 2005;28:1253-1263.

211. Waterval WA, Scheijen JL, Ortmans-Ploemen MM, Habetsvan der Poel CD, Bierau J. Quantitative UPLC-MS/MS analysis of underivatised amino acids in body fluids is a reliable tool for the diagnosis and follow-up of patients with inborn errors of metabolism. Clin Chim Acta. 2009;407:36-42.

212. Hewitson HB, Wheat TE, Diehl DM. Application of UPLC amino acid analysis solution to foods and feeds. Am Lab. 2009;41:22-26.

213. Ozturk SS, Thrift JC, Blackie JD, Naveh D. Real-time monitoring and control of glucose and lactate concentrations in a mammalian cell perfusion reactor. Biotechnol Bioeng. 1997;53: 372-378.

214. Baker KN, Rendall MH, Patel A, Boyd P, Hoare M, Freedman $\mathrm{RB}$, James DC. Rapid monitoring of recombinant protein products: a comparison of current technologies. Trends Biotechnol. 2002;20:149-156.

215. Schügerl K. Progress in monitoring, modeling and control of bioprocesses during the last 20 years. J Biotechnol. 2001;85: 149-173.

216. Meyerhoff ME, Trojanowicz M, Palsson BØ. Simultaneous enzymatic/electrochemical determination of glucose and L-glutamine in hybridoma media by flow-injection analysis. Biotechnol Bioeng. 1993;41:964-969.

217. Kumar MA, Thakur MS, Senthuran A, Senthuran V, Karanth NG, Hatti-Kaul R, Mattiasson B. An automated flow injection analysis system for on-line monitoring of glucose and L-lactate during lactic acid fermentation in a recycle bioreactor. World $J$ Microbiol Biotechnol. 2001;17:23-29.

218. Stoll TS, Ruffieux PA, von Stockar U, Marison IW. Development of an on-line control system for the cultivation of animal cells in a hollow-fiber reactor using flowing injection analysis and a visual programming language. J Biotechnol. 1996;51:3748.

219. Schügerl K, Hitzmann B, Jurgens H, Kullick T, Ulber R, Weigal B. Challenges in integrating biosensors and FIA for on-line monitoring and control. Trends Biotechnol. 1996;14:21-31.

220. Yano T, Harata M. Prediction of the concentration of several constituents in a mouse-mouse hybridoma culture by near infrared spectroscopy. J Ferment Bioeng. 1994;77:659-662.

221. Zhou X, Chung H, Arnold MA, Rhiel M, Murhammer DW. Selective measurement for glutamine and asparagine in aqueous media by near-infrared spectroscopy. In: Rogers KR, Mulchandani A, Zhou W, editors. Biosensor and Chemical
Sensor Technology: Process Monitoring and Control. Washington, DC: ACS Books; 1995:116-132.

222. Chung H, Arnold MA, Rhiel M, Murhammer DW. Simultaneous measurements of glucose, glutamine, ammonia, lactate, and glutamate in aqueous solutions by near-infrared spectroscopy. Appl Spectrosc. 1996;50:270-276.

223. Cadet F, Robert C, Offmann B. Simultaneous determination of sugars by multivariate analysis applied to mid-infrared spectra of biological samples. Appl Spectrosc. 1997;51:369-375.

224. Bellon-Maurel V, Vallat C, Goffinet D. Quantitative analysis of individual sugars during starch hydrolysis by FT-IR/ATR spectrometry. II. Influence of external factors and wavelength parameters. Appl Spectrosc. 1995;49:563-568.

225. Goldsby RA, Kindt TJ, Osborne BA, Kuby J. Enzyme-linked immunosorbent assay. In: Goldsby RA, Kindt TJ, Kuby J, Osborne BA, editors. Immunology, 5th ed. New York: Freeman; 2003:148-160.

226. Jacquemart R, Chavane N, Durocher Y, Hoemann C, de Crescenzo G, Jolicoeur M. At-line monitoring of bioreactor protein production by surface plasmon resonance. Biotechnol Bioeng. 2008;100:184-188.

227. Szmacinski H, Smith DS, Hanson MA, Kostov YV, Lakowicz JR, Rao G. A novel method for monitoring monoclonal antibody production during cell culture. Biotechnol Bioeng. 2008; 100:448-457.

228. Daigo K, Sugita S, Mochizuki Y, Iwanari H, Hiraishi K, Miyano K, Kodama T, Hamakubo T. A simple hybridoma screening method for high-affinity monoclonal antibodies using the signal ratio obtained from time-resolved fluorescence assay. Anal Biochem. 2006;351:219-228.

229. Jones JJ, Wilkins CL, Cai Y, Beitle RR, Liyanage R, Lay JO Jr. Real-time monitoring of recombinant bacterial proteins by mass spectrometry. Biotechnol Prog. 2005;21:17541758.

230. Fang B, Gao Y, Li M, Wang G, Li Y. Application of functionalized Ag nanoparticles for the determination of proteins at nanogram levels using the resonance light scattering method. Mind Cult Activ. 2004;147:81-86.

231. Kumar S, Harrison N, Richards-Kortum R, Sokolov K. Plasmonic nanosensors for imaging intracellular biomarkers in live cells. Nano Lett. 2007;7:1338-1343.

232. Gerber S, Reil F, Hohenester U, Schlagenhaufen T, Krenn JR, Leitner A. Tailoring light emission properties of fluorophores by coupling to resonance-tuned metallic nanostructures. Phys Rev B. 2007;75:073404-4.

233. Giakos GC, Meehan K, Tuma M. Exploitation of enhanced fluorescence via cross-coupling principles toward the design of an optical integrated thin-film sensor for nanotechnology and biomedical applications. IEEE Trans Instrum Meas. 2002;51: 970-975.

234. Kaneko Y, Nimmerjahn F, Ravetch JV. Anti-inflammatory activity of immunoglobulin $\mathrm{G}$ resulting from $\mathrm{Fc}$ sialylation. Science. 2006;313:670-673.

235. Furth AJ. Methods for assaying nonenzymatic glycosylation. Anal Biochem. 1988;175:347-360.

236. Parekh RB, Patel TP. Comparing the glycosylation patterns of recombinant glycoproteins. Trends Biotechnol. 1992;10:276280.

237. Hooker A, James D. Analysis of glycoprotein heterogeneity by capillary electrophoresis and mass spectrometry. Mol Biotechnol. 2000;14:241-249.

238. Wagner-Rousset E, Bednarczyk A, Bussat MC, Colas O, Corvaïa N, Schaeffer C, Van Dorsselaer A, Beck A. The way forward, enhanced characterization of therapeutic antibody glycosylation: comparison of three level mass spectrometry-based strategies. J Chromatogr B. 2008;872:23-37.

239. Taverna M, Tran NT, Merry T, Horvath E, Ferrier D. Electrophoretic methods for process monitoring and the quality assessment of recombinant glycoproteins. Electrophoresis. 1998;19:2572-2594.

240. Li YC, Larrson EL, Jungvid H, Galaev IY, Mattiasson B. Shielding of protein-boronate interactions during boronate chromatography of neoglycoproteins. J Chromatogr A. 2001; 909:137-145. 
241. Merry T. Current techniques in protein glycosylation analysis. A guide to their application. Acta Biochim Pol. 1999;46:303-314.

242. Yan B, Valliere-Douglass J, Brady L, Steen S, Han M, Pace D, Elliot S, Yates Z, Yihong H, Balland A, Weichun W, Pettit D. Analysis of post-translational modifications in recombinant monoclonal antibody IgG1 by reversed-phase liquid chromatography/mass spectrometry. J Chromatogr A. 2007;1164:153161.

243. Perkins M, Theiler R, Lunte S, Jeschke M. Determination of the origin of charge heterogeneity in a murine monoclonal antibody. Pharm Res. 2000;17:1110-1117.

244. Cacia J, Keck R, Presta LG, Frenz J. Isomerization of an aspartic acid residue in the complementarity-determining regions of a recombinant antibody to human IgE: identification and effect on binding affinity. Biochemistry. 1996;35:1897-1903.

245. He XZ, Que AH, Mo JJ. Analysis of charge heterogeneities in mAbs using imaged CE. Electrophoresis. 2009;30:714-722.

246. Dillon TM, Bondarenko PV, Ricci MS. Development of an analytical reversed-phase high-performance liquid chromatography-electrospray ionization mass spectrometry method for characterization of recombinant antibodies. J Chromatogr A. 2004;1053:299-305.

247. Schmidt F. Optimization and scale up of industrial fermentation processes. Appl Microbiol Biotechnol. 2005;68:425-435.
248. Yang J-D, Lu C, Stasny B, Henley J, Guinto W, Gonzalez C, Henley J, Fung M, Collopy B, Benjamino M, Gangi J, Hanson $\mathrm{M}$, Ille E. Fed-batch bioreactor process scale-up from 3-L to 2,500-L scale for monoclonal antibody production from cell culture. Biotechnol Bioeng. 2007;98:141-154.

249. Marks D. Equipment design considerations for large scale cell culture. Cytotechnology. 2003;42:21-33.

250. Bylund F, Collet E, Enfors SO, Larsson G. Substrate gradient formation in the large-scale bioreactor lowers cell yield and increases by-product formation. Bioprocess Biosyst Eng. 1998; 18:171-180.

251. Langheinrich $\mathrm{C}$, Nienow AW. Control of $\mathrm{pH}$ in large-scale, free suspension animal cell bioreactors: alkali addition and $\mathrm{pH}$ excursions. Biotechnol Bioeng. 1999;66:171-179.

252. Osman JJ, Birch J, Varley J. The response of GS-NS0 myeloma cells to single and multiple $\mathrm{pH}$ perturbations. Biotechnol Bioeng. 2002;79:398-407.

253. Serrato JA, Palomares LA, Meneses-Acosta A, Ramírez OT. Heterogeneous conditions in dissolved oxygen affect N-glycosylation but not productivity of a monoclonal antibody in hybridoma cultures. Biotechnol Bioeng. 2004;88:176-188.

Manuscript received Jun. 17, 2009, and revision received Aug. 25, 2009. 